\title{
The Effect of Mental Health and Perfectionism on Ethical Accounting Decision Making with the Mediating Role of Procrastination
}

\author{
Saeed Hosseinpoor \\ PhD student in Accounting, Qazvin Branch, Islamic Azad University, \\ Qazvin,Iran(s.hosseinpoor2011@gmail.com) \\ Sina Kheradyar* \\ Assistant Professor of Accounting, Rasht Branch, Islamic Azad University, \\ Rasht, Iran(Corresponding author), Sinakheradyar@gmail.com
}

\author{
Ali Khozain \\ Assistant Professor of Accounting, Aliabad Katoul Branch, Islamic Azad \\ University, Aliabad Katoul,Iran(khozain@yahoo.com) \\ Fazel Mohamadi nodeh \\ Assistant Professor of Financial Management, Lahijan Branch, Islamic Azad \\ University, Lahijan, Iran(Mnfazel@gmail.com)
}

\begin{abstract}
:
Honest financial reporting leads to optimal stakeholder decision making and will lead to the economic prosperity of communities through the optimal allocation of resources. Therefore, it is very important to pay attention to the factors that affect honest financial reporting. The purpose of this study is to investigate factors such as mental health, perfectionism and procrastination of accountants on honest financial reporting. The data were obtained using questionnaires and by a sample of senior accountants of companies listed on the Tehran Stock Exchange. Hypotheses are tested by structural equation modeling using PLS software. Findings showed that accountants mental health and perfectionism lead to procrastination and honest reporting. On the other hand, the effect of procrastination on honest reporting and the mediating effect of procrastination has not been confirmed. Paying attention to the characteristics of mental health and trying to promote it in the organization, especially among accountants and financial managers, leads to improve the reporting process and increases honesty in presenting companies financial reports and optimal decisions of different user groups.
\end{abstract}

Keywords: honest reporting, mental health, perfectionism, procrastination.

Copyrights:

This license only allowing others to download your works and share them with others as long as they credit you, but they can't change them in any way or use them commercial. 


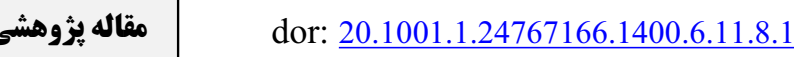

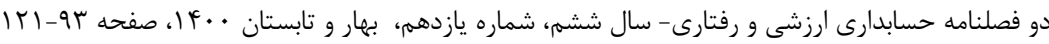

\title{
بررسى اثر سلامت روانى و كمال كرايى بر تصميمكيرى اخلاقى حسابداران با نقش ميانجى اهمال كارى
}

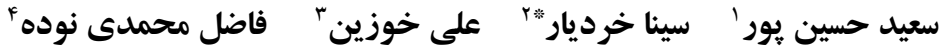

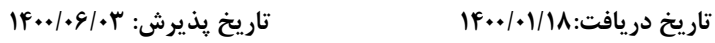

جָكيله

تصميم كيرى اخلاقى حسابداران منجر به ارائه كزارشكرى صادقانه شده و از طريق تخصيص

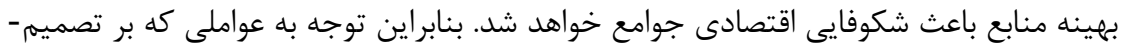

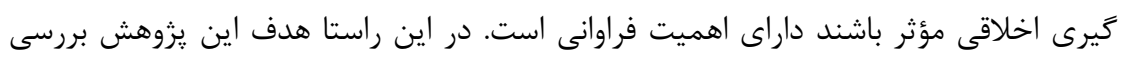

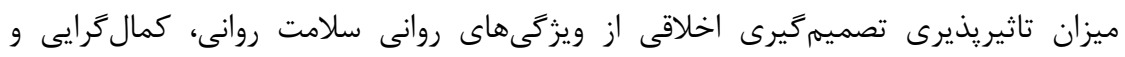

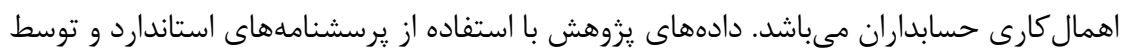

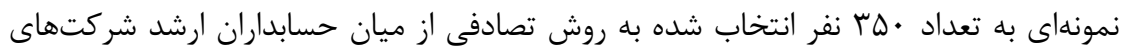

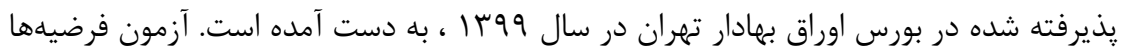

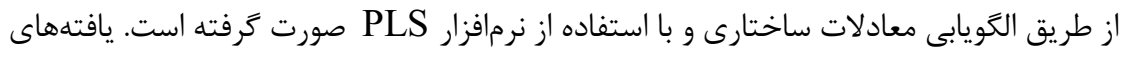

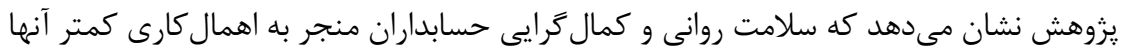

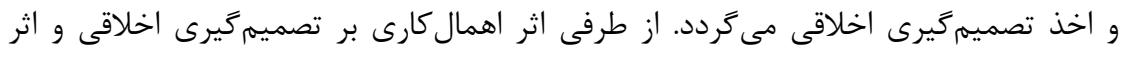

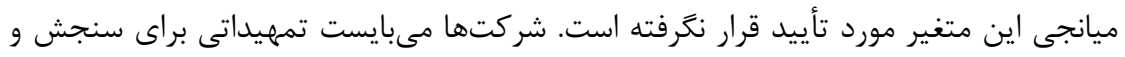

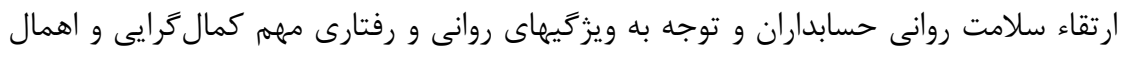

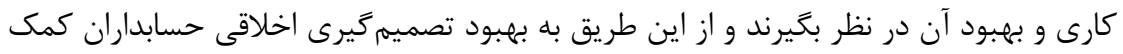

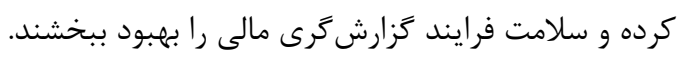

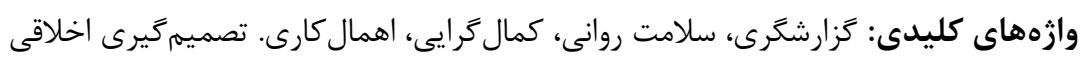

'دانشجوى دكترى گروه حسابدارى، واحد قزوين، دانشًاه آزاد اسلامى، قزوين، ايران. s.hosseinpoor2011@gmail.com "استاديار كروه حسابدارى، واحد رشت، دانشخاه آزاد اسلامى، رشت، ايران (نويسنده مسئول)،

Sinakheradyar@gmail.com "استاديار گروه حسابدارى، واحد على آباد كتول ، دانشگاه آزاد اسلامى، علىآباد كتول، ايران khozain@yahoo.com Mnfazel@gmail.com استادياركروه مديريت مالى، واحد لاهيجان، دانشكاه آزاد اسلامى، لاهيجان، ايران 
در سالهاى اخير يكى از متغيرهاى مهمى كه بيش از پيش مورد توجه يزوهشكَران حوزه

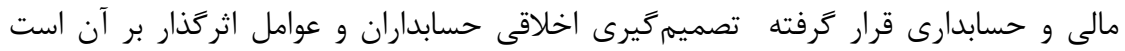

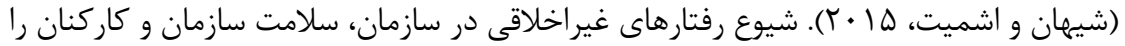

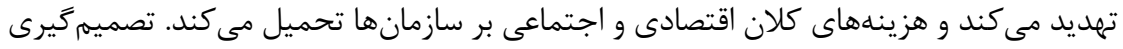

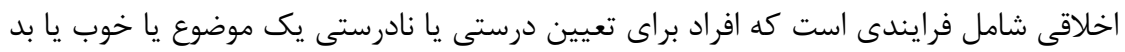
بودن يك عمل يا تصميم از آن استفاده مى كنند و در يك فرايند جهار مرحلهاى شامل شناخ فاخت

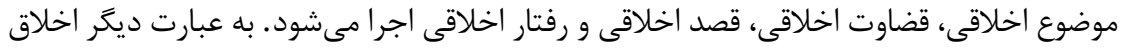

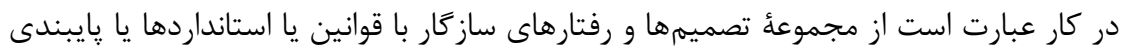

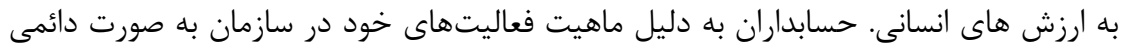

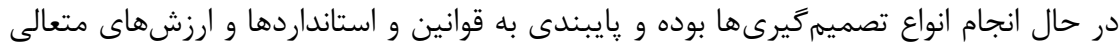

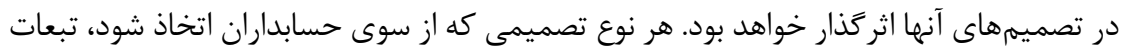

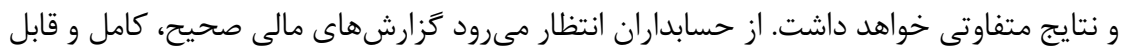
اعتماد ارائه كرده و ضمن انجام وظايف حرفهاى خود با مسئوليتيذيرى رفتار كنند (خاندوزى و

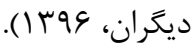

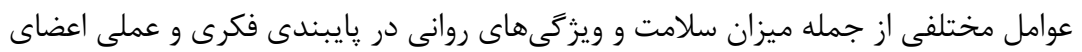
حرفه حسابدارى در تصميم گيرى اخلاقى و در كزارشكرى نقش دارند. از آنجا كه حالات روات روحى

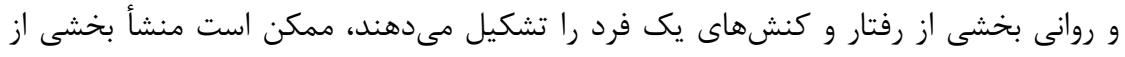

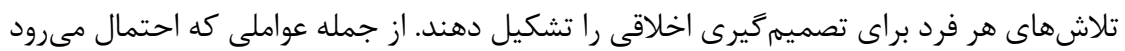

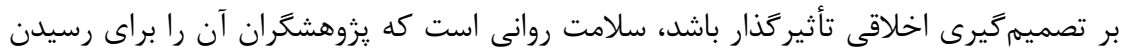

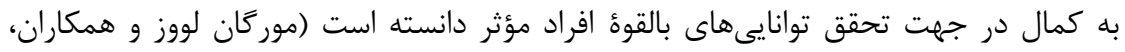

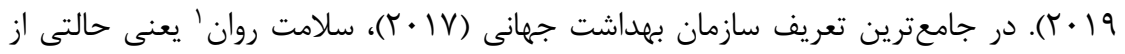

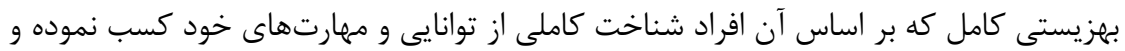

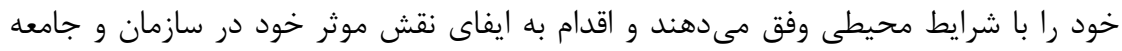

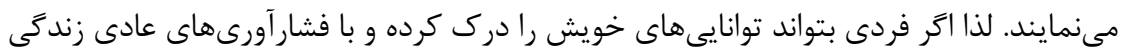

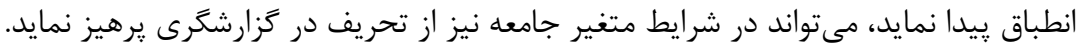

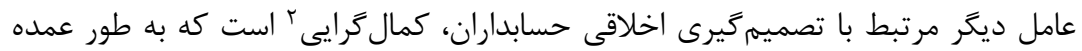

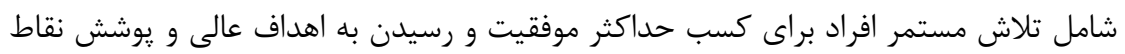

1 - Mental Health

2 - perfectionism 


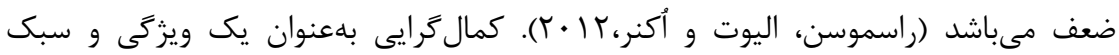

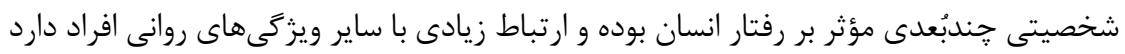

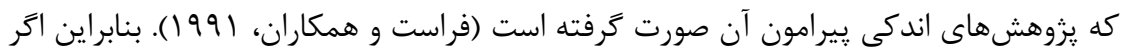

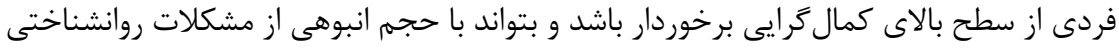

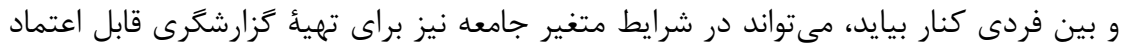

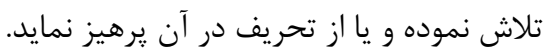

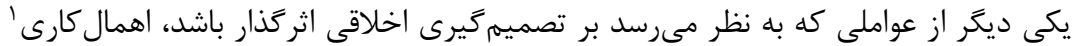

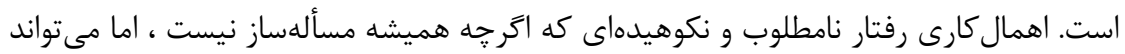

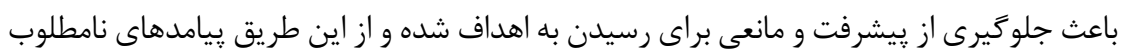

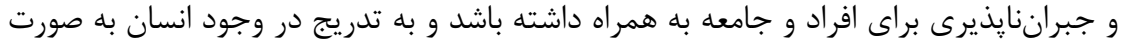

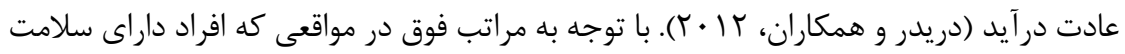

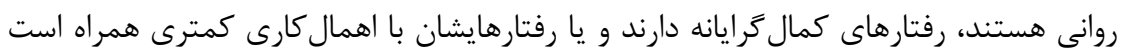

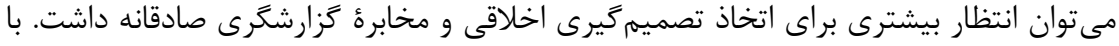

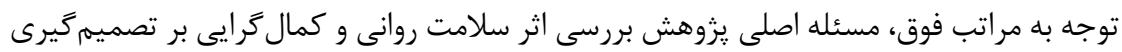

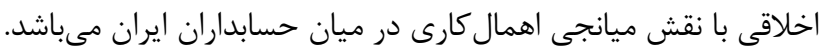

\section{r- مبانى نظرى و بيشينهُ يزوهش}

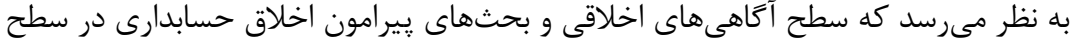

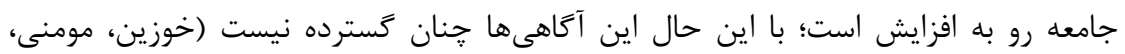

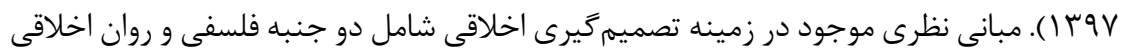
شناختى است. با نكاهى به مطالعات بيشين مشخص مهىشود كه فلسفه اخلاقى به طور عمده به به

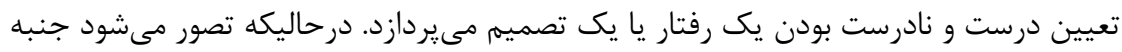

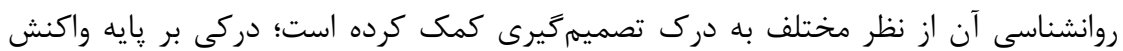

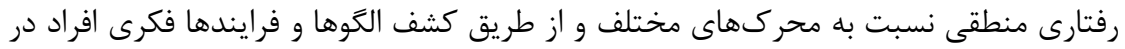

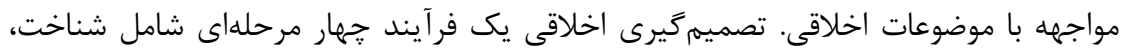

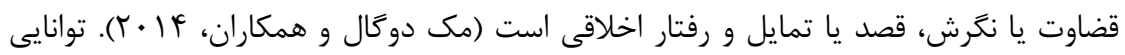
افراد در تشخيص اين واقعيت كه در يك موقعيت اخلاقى قرار دارند و نياز به قضاوت اخلاقداقيى وجود دارد، متفاوت است و اين توانيى تحث تاثير عوامل متفاوتى از جمله خصوصيات روانى افراد

1 - Procrastination 
قرار مى گيرد. تا زمانى كه فرد قادر به تشخيص موقعيت اخلاقى نشود، مراحل ديخر بىمعنا بوده اخدي

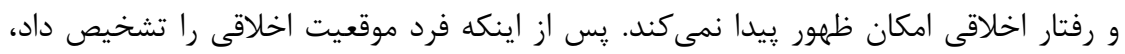

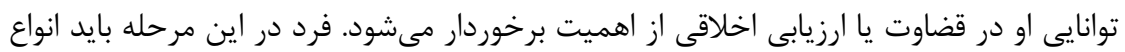

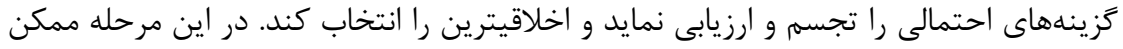

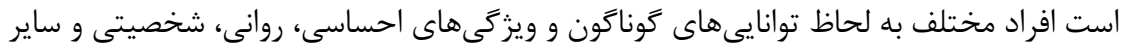

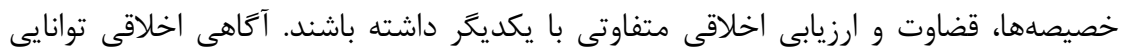
تفسير يك وضعيت به عنوان اخلاقى بودن است. قضاوت اخلاقى توانايى تصميمكيرنده است كه

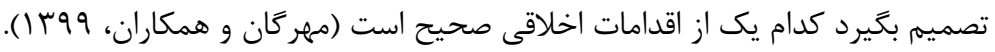

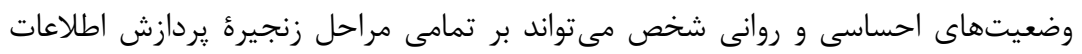

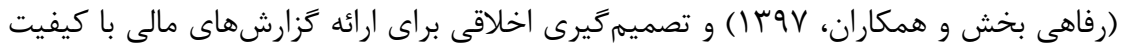

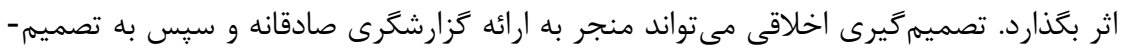

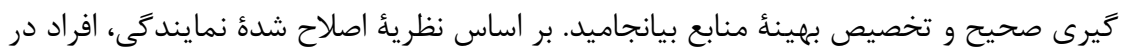

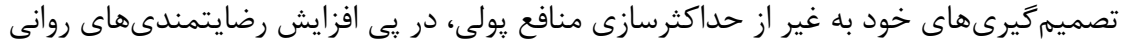

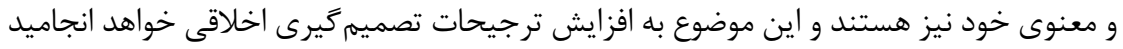

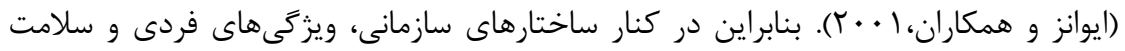

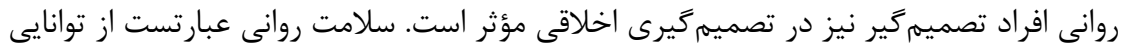

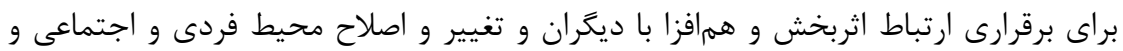

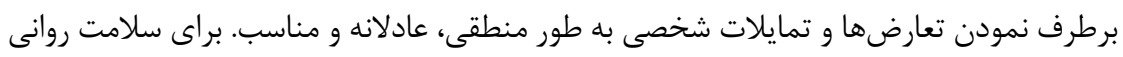

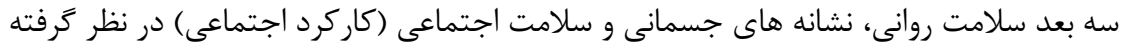

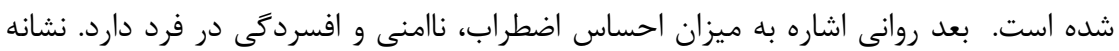

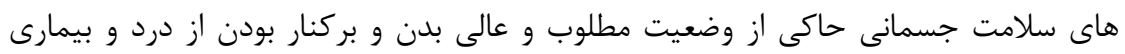

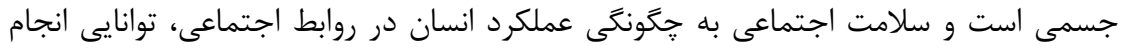

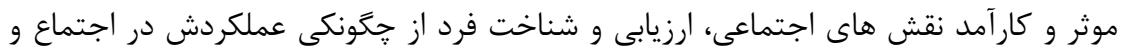

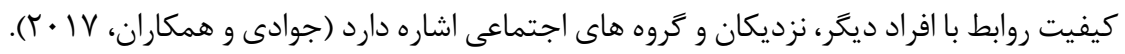

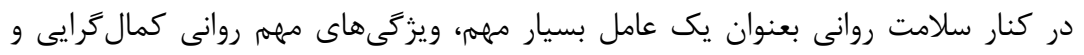

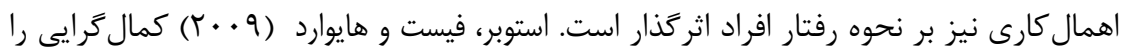

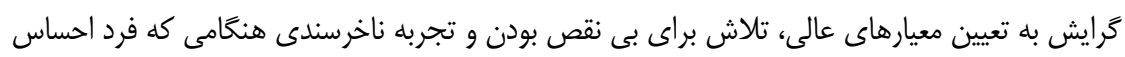

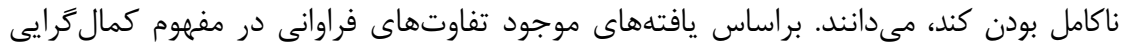

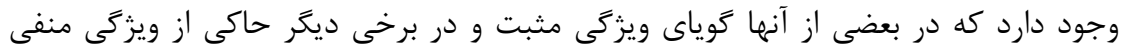

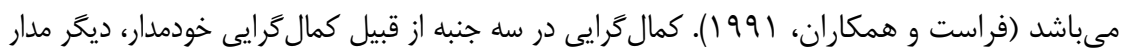




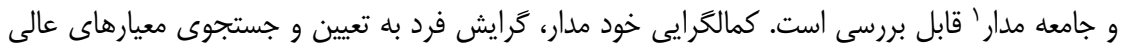

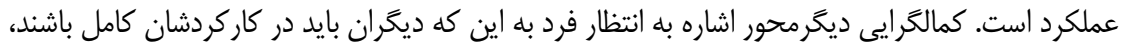

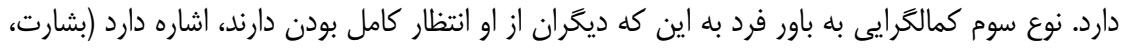

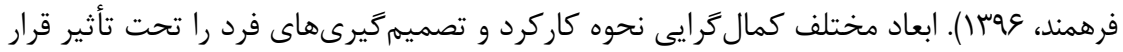

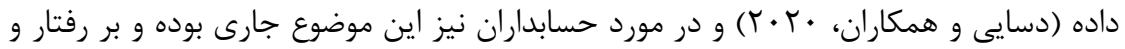

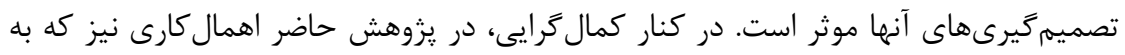

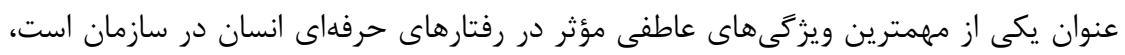
مورد مطالعه قرار خواهد كرفت.

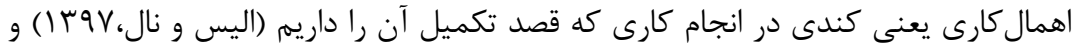

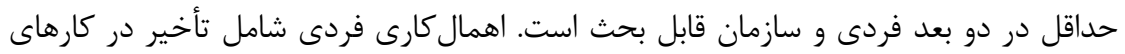

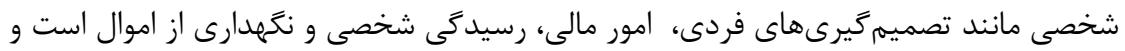

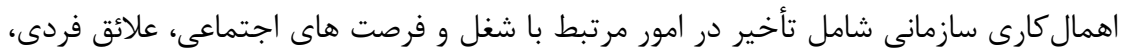

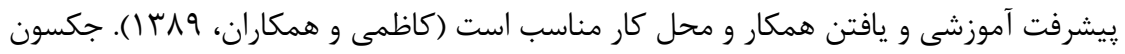

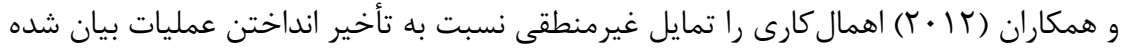

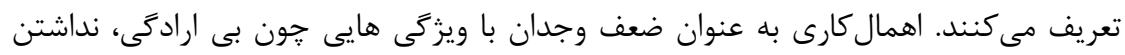

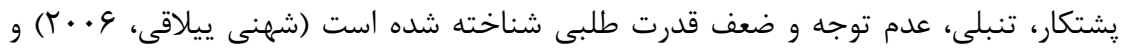

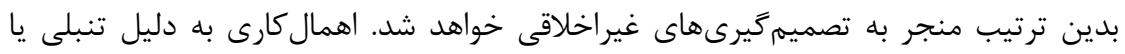

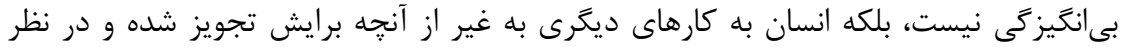

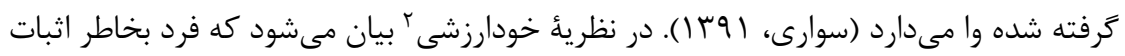

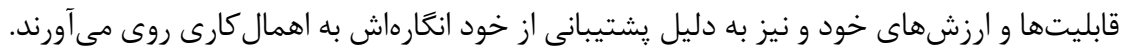

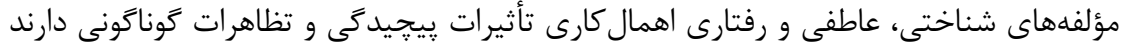

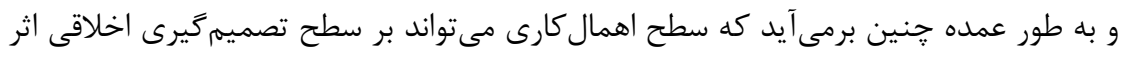

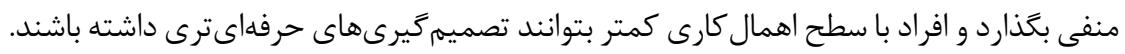
مباحث فوق بيانكر آن است كه سلامت روانى، كمال

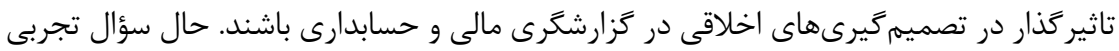

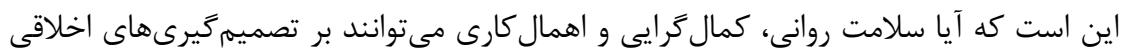

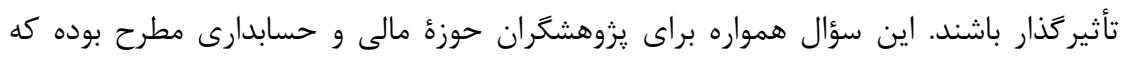

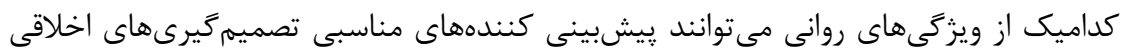

1- self-oriented perfectionism; other-oriented perfectionism;social-oriented perfectionism 2 - Self-esteem theory 


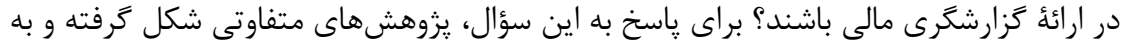

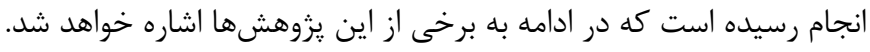

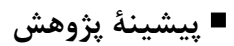

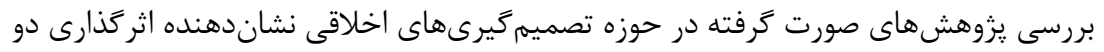

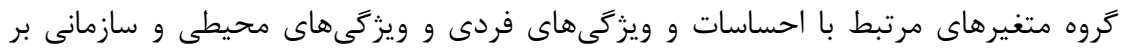

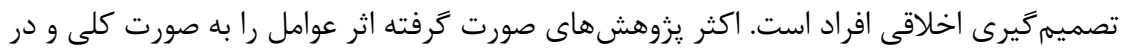

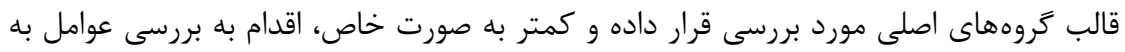

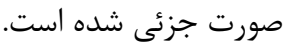

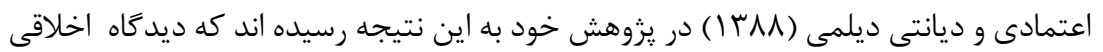
مديران بر كيفيت كزارشهاى مالى موثر است و بعلاوه آرمانكرايى اثر مثبت و معنى دائى دارى بردي

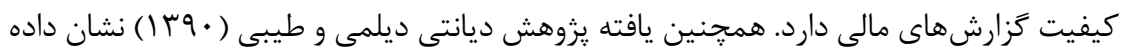
كه بعد اخلاقى آرمانكرايى مديران بر كيفيت سود كزارش شده توسط آنها

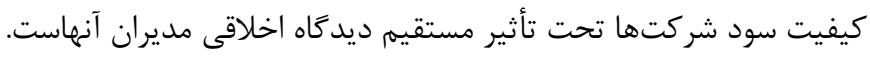

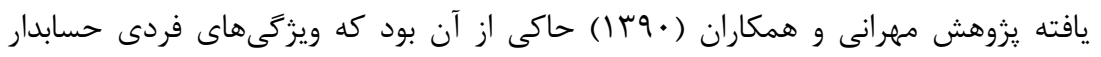

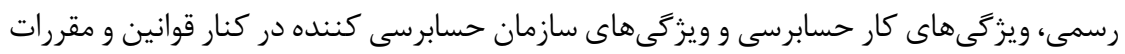

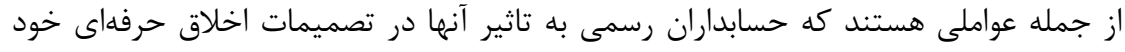

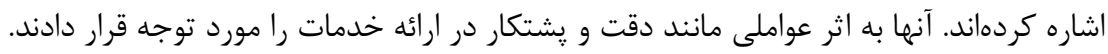

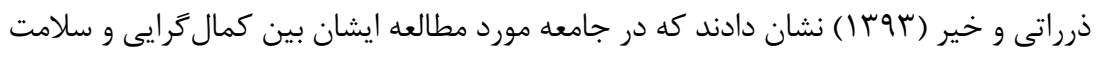
روانى رابطه مثبت و معنى دار و بين اهمال كارى و سلامت روانى ارتباط معكوس و معنى دارى دارى داردان

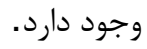

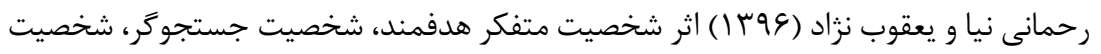

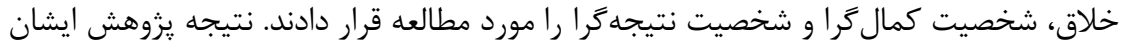

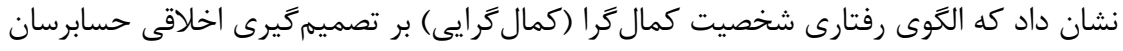

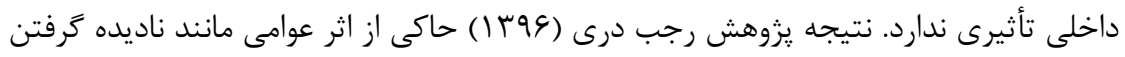

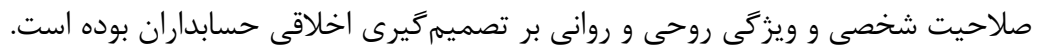

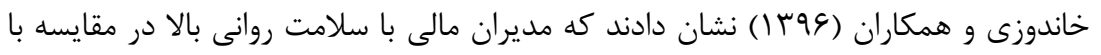

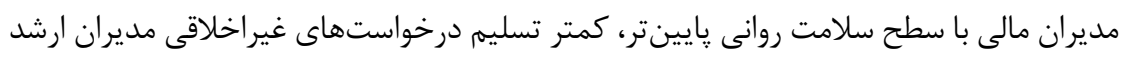

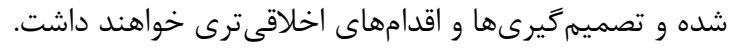

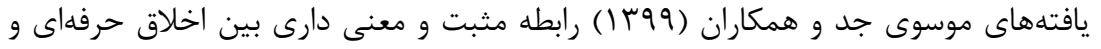

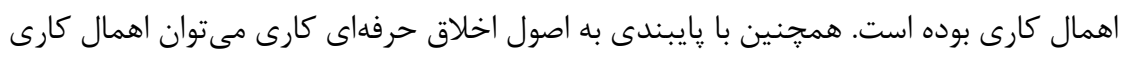


را در سازمان كاهش داده و با نهادينه كردن اين اصول در سازمان منجر به بالا رفتن كارايى سازمان شد.

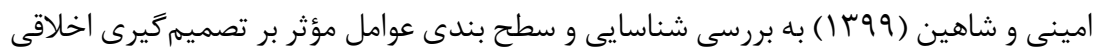

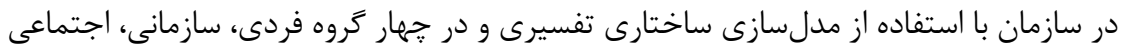

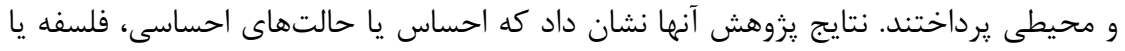

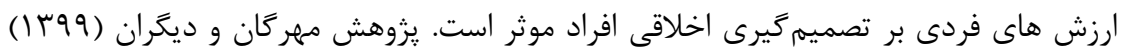

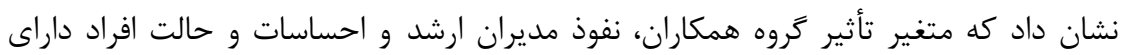

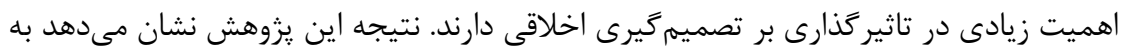

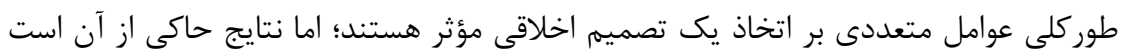

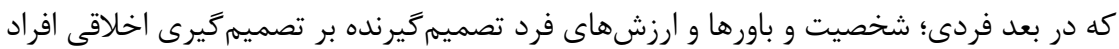

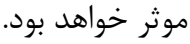

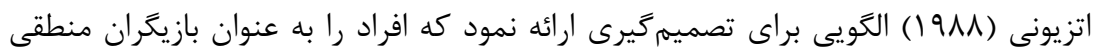

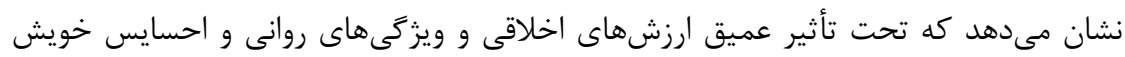

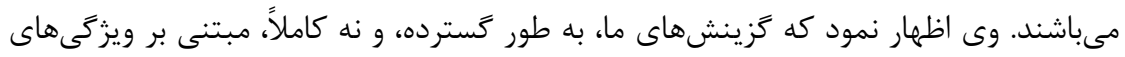

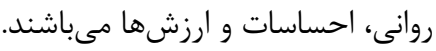

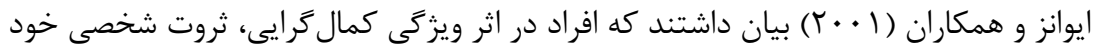

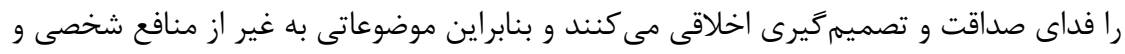

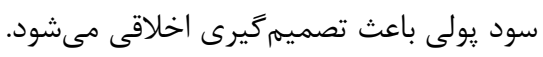

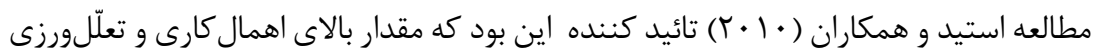

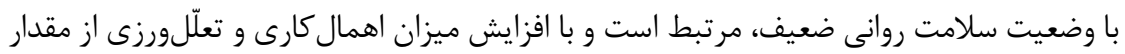

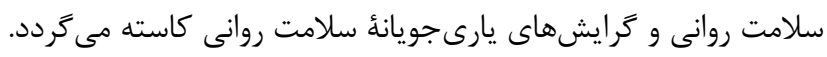

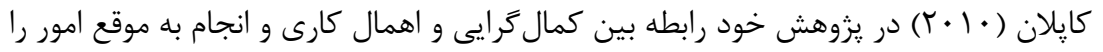

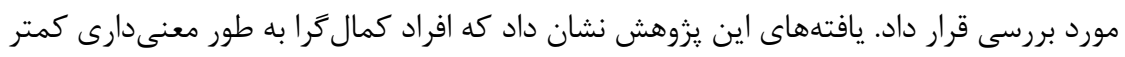

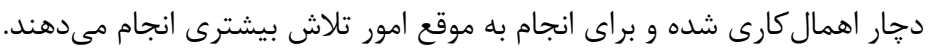

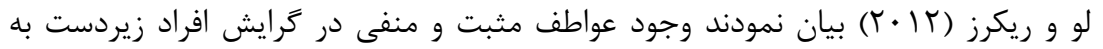

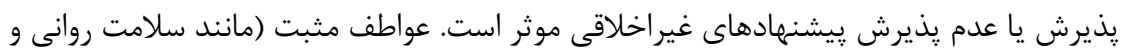

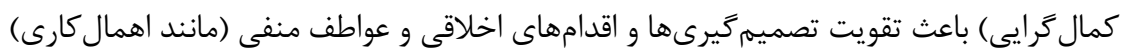

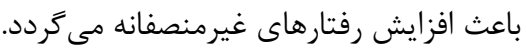




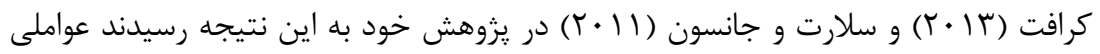

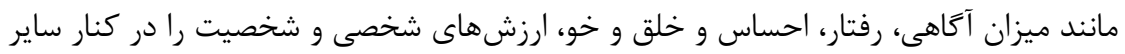
عوامل بر تصميمخيرى اخلاقى موثر است.

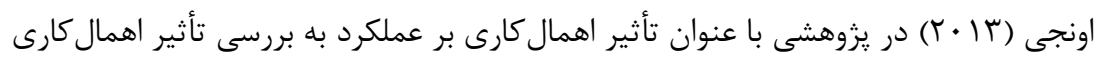

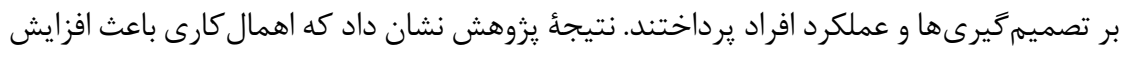

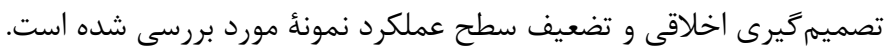

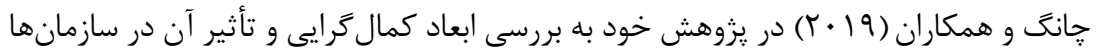

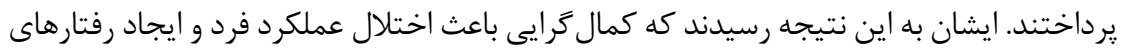

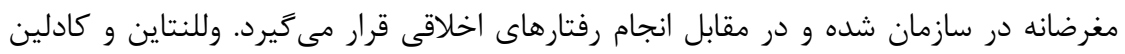

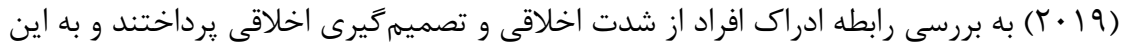

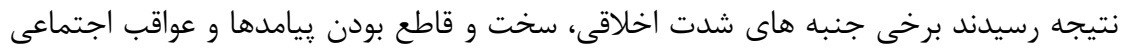

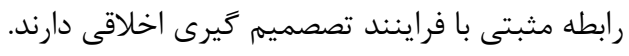

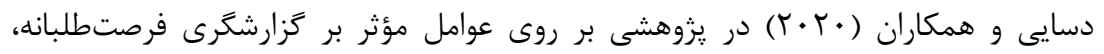

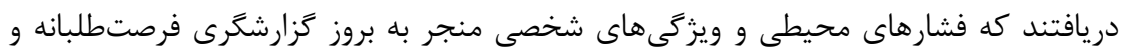

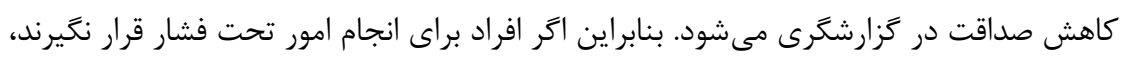

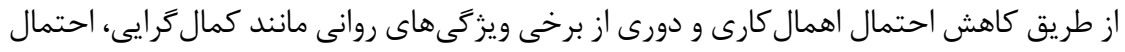

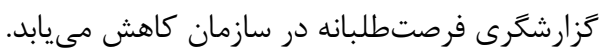

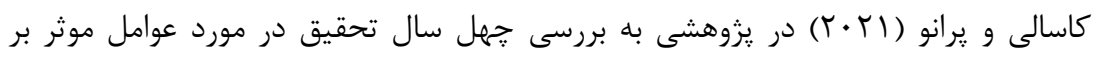

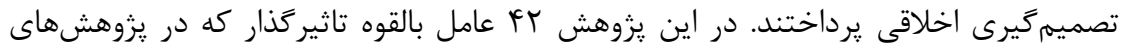

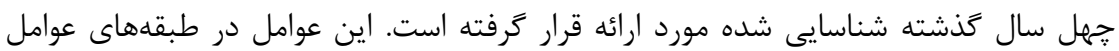

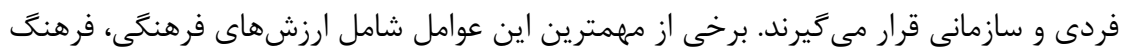

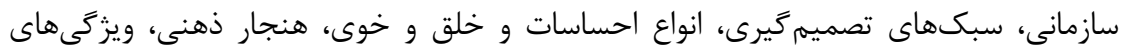

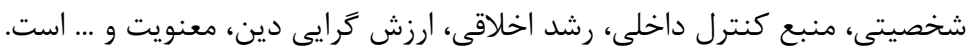

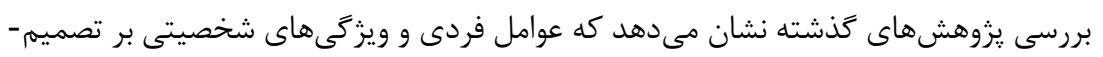

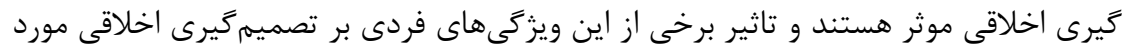

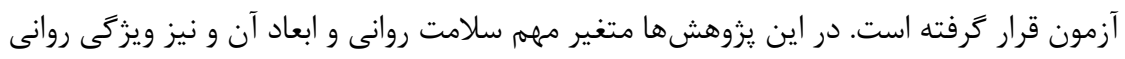

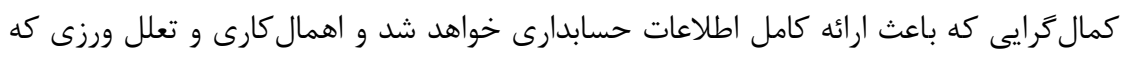

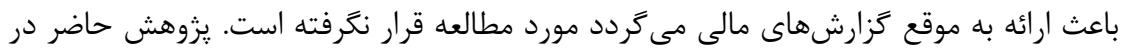

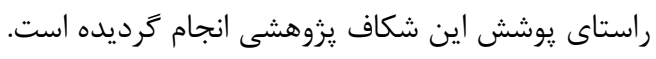


يزوهشكران در كذشته تلاش كردهاند كه به تبيين اهميت نقش و اثر ويزگكىهاى شخصيتى و

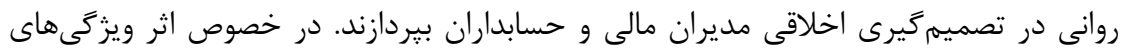

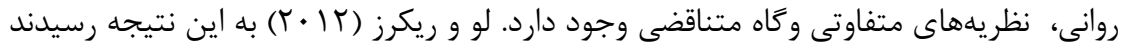

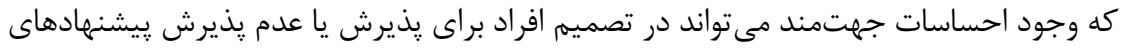

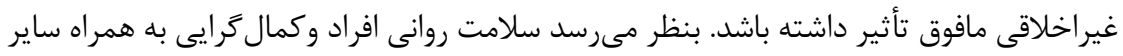

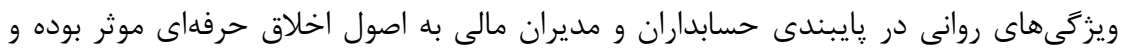

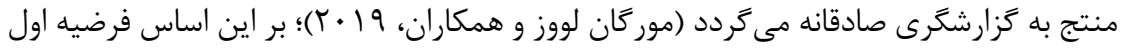
و دوم يزوهش بشرح زير شكل كرفته است: فرضيئ اول: حسابداران با سطح سلامت روانى بالاتر با احتمال بيشترى اقدام به تصميمكيرى

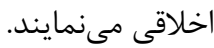
فرضيئ دوم: حسابداران با سطح كمال

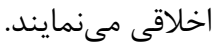

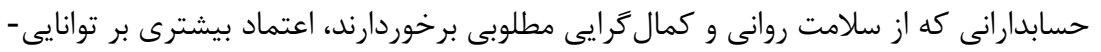

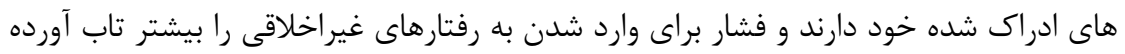

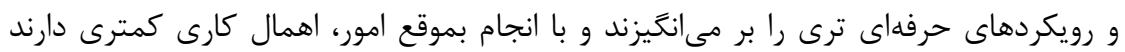

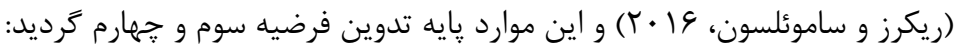
فرضئٔ سوم : حسابداران با سطح سلامت روانى بالاتر با احتمال كمترى اقدام به اهمال كارى

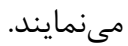
فرضئه جهارم : حسابداران با سطح كمال كرايى بالاتر با احتمال كمترى اقدام به اهمال كارى مىنمايند.

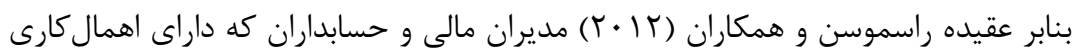
هستند، تلاش كمترى در دستيابى به اهداف فردى و سازمانى خود انجام داده و نتيجه فعاليت آنها ارائُٔ كزارشهاى توام با تحريف بيشتر خواهد بود كه اين موضوع با ارئه فرضيه ينجم مورد

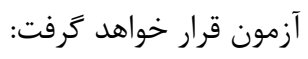

فرضيئ هِنجم: حسابداران با سطح اهمال كارى بالاتر با احتمال كمترى اقدام به تصميمَيرى

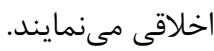

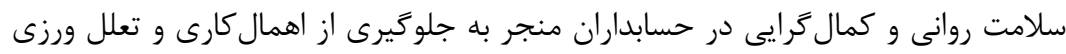

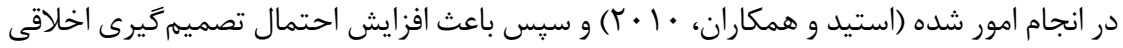

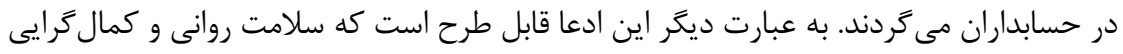


از طريق انجام به موقع امور باعث افزايش سطح رفتارهاى اخلاقى و جلوكيرى از تصميمَيريهاى

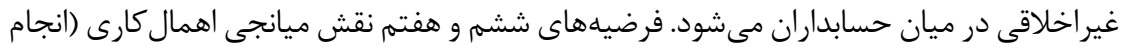

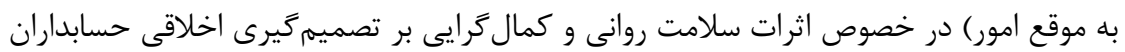
ا ا مورد بررسى قرار مى دهد. فرضيئ ششم: حسابداران با سطح سلامت رورد روانى بالاتر از طريق اهمال كارى كمتر، با احتمال بيشترى اقدام تصميمَيرى اخلاقى مئمايند. فرضيئ هفتم: حسابداران با سطح كمال كر ايى بالاتر از طريق اهمال كارى كمتر، با احتمال بيشترى اقدام به تصميم خيرى اخلاقى مىنمايند. شكل 1 : مدل مفهومى براى آزمون فرضيدهاى يزوهش

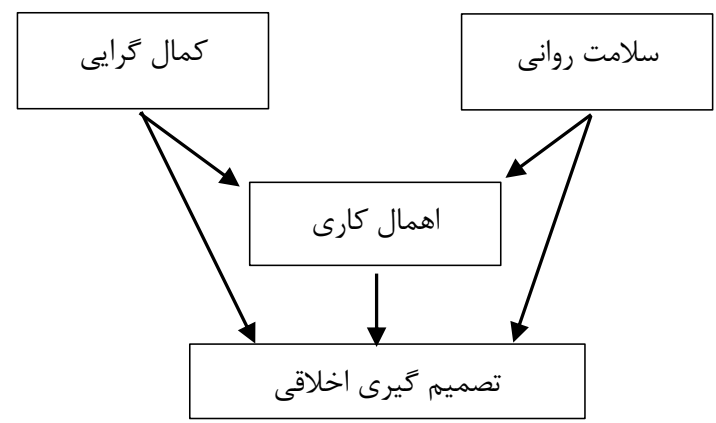

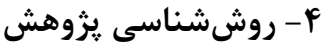

يزوهش حاضر از نظر هدف، كاربردى و از نظر روش كردآورى اطلاعات، توصيفى و از نوع

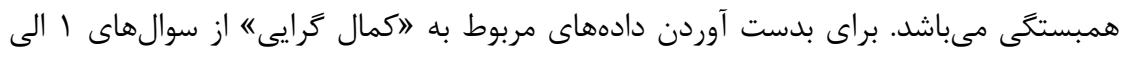

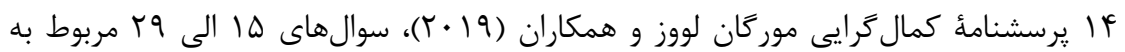

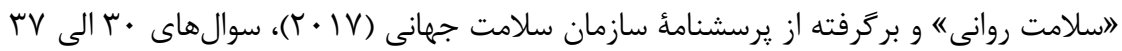

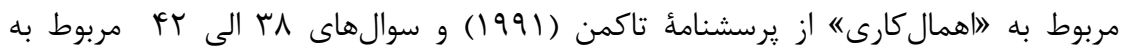

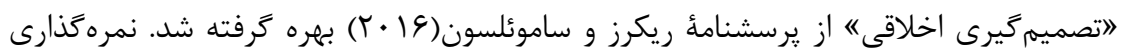
كليه يرسشنامهها بر اساس طيف ليكرت صورت گرفته است. براى آزمون فرضيههاى يزوهي،

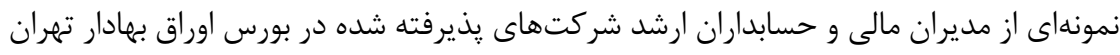

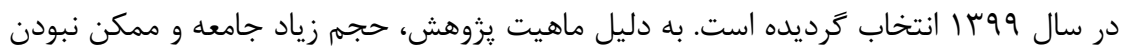
بررسى تمام جامعأ آمارى از روش نمونهَّيرى در دسترس استفاده شد. حجم نمونه نيز با استفاده 


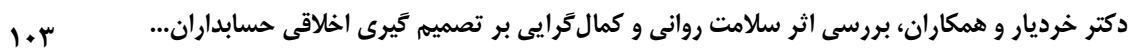

از جدول موركان • •هץ نفر تعيين گرديد و به اين منظور، به همين تعداد اقدام به جمعآورى يرسشنامه گرديد.

براى آزمون فرضيهها و مدل يزوهش ابتدا دادههاى بدست آمده از يرسشنامههاى توزيع شده

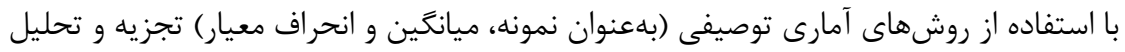

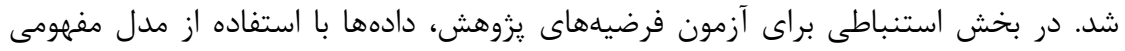

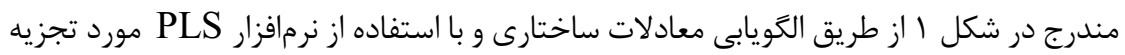
و تحليل قرار گرفت. در اين يزوهش تصميم كيرى اخلاقى به عنوان متغير ينهان وابسته در نظر

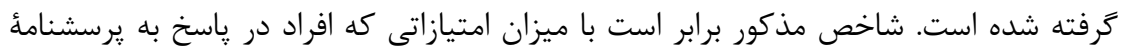

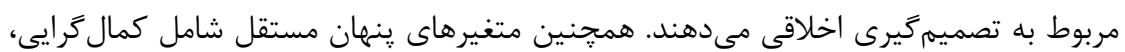

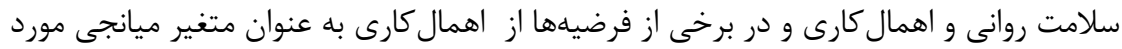

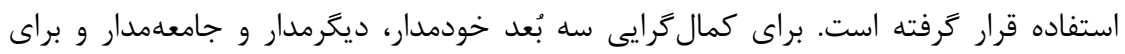

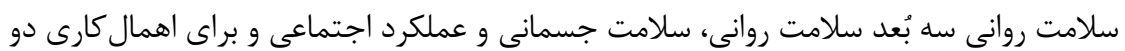
بُعد اهمال كارى فردى و سازمانى در نظر كَرفته شده است.

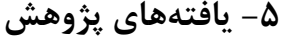

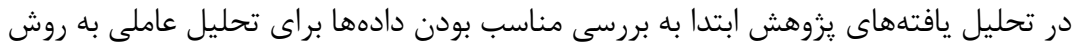

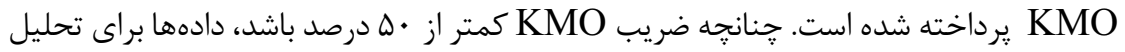

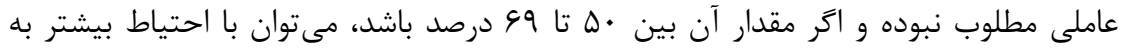

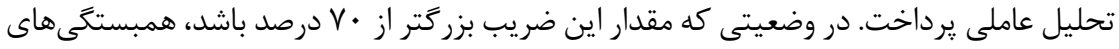

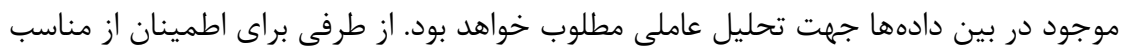

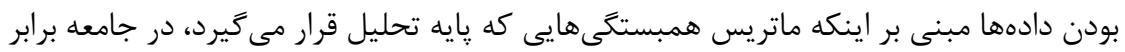

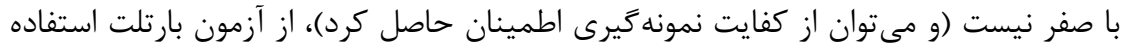

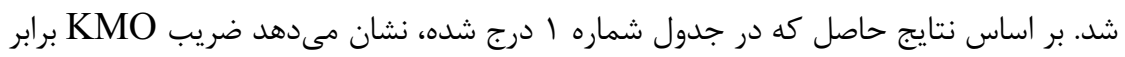

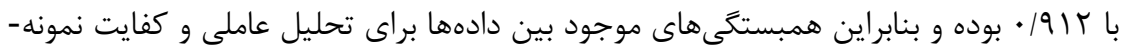

$$
\text { كيرى مناسب است. }
$$

جدول ا : آزمون KMO و بارتلت

\begin{tabular}{|c|c|c|}
\hline \multicolumn{2}{|c|}{ آزمون كفايت دادههاى كيسر_ميير و اوكلين } &.$/ 917$ \\
\hline \multirow{3}{*}{ 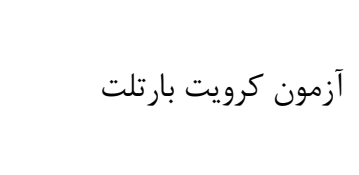 } & آماره كاى-اسكوئر & ITIKT/VF. \\
\hline & درجة آزادى & ᄉs \\
\hline & سطح معنادارى & \\
\hline
\end{tabular}


با توجه به عدد KMO (بزر كتر از • لادرصد) و عدد معنادارى آزمون بارتلت (سطح معنادارى

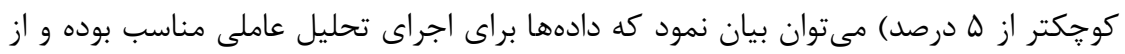

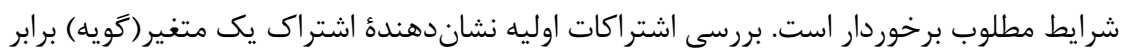

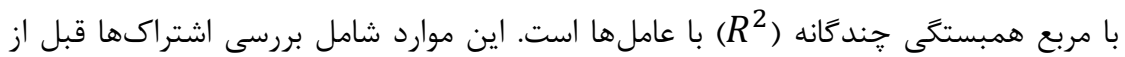

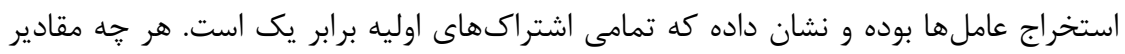

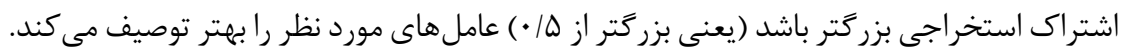

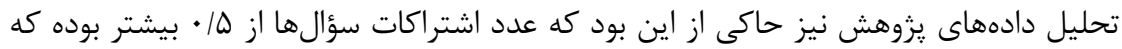

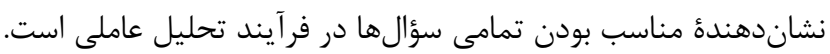

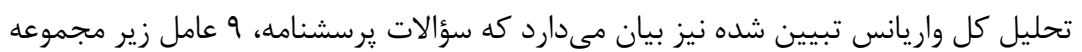

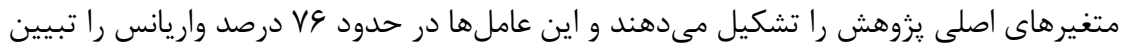

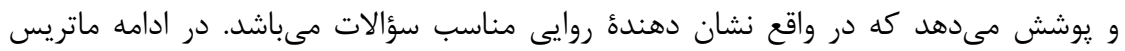

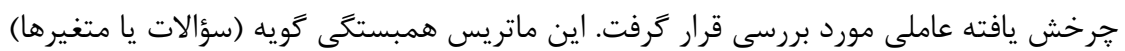

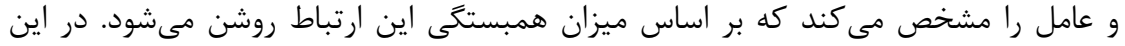

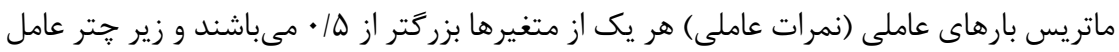

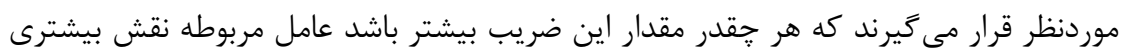
در كل تغييرات (واريانس) متغير موردنظر دارد.

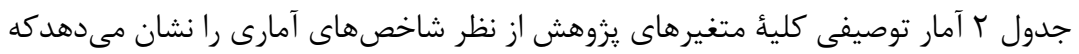

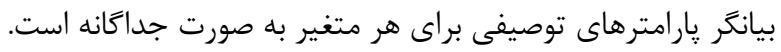

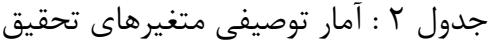

\begin{tabular}{|c|c|c|c|c|c|c|}
\hline واريانس & انحراف & ميانكين & بيشترين & كمترين & تعداد & متغير \\
\hline.$/ Q T F$ & . IVYFI. & $T / V \Lambda \cdot T$ & $\Delta / \cdot \cdot \cdot$ & $1 / 41$ & ra. & كمال ترايى \\
\hline .1019 &.$/ V I \wedge \& q$ & T/GFVA & $F / \Lambda$. & $1 / \cdot \cdot$ & ra. & سلامت روانى \\
\hline$\cdot / \Delta V \Delta$ & $\cdot / V \Delta \wedge \Delta \wedge$ & r/ATVD & $\Delta / \cdot \cdot \cdot$ & $1 / \cdot \cdot$ & $r \Delta$. & همال كارى \\
\hline - IATV & .9 .941 & T/VVMI & $\Delta / \cdot \cdot$ & $1 / \cdot \cdot$ & $r \Delta$. & تصلاقيى \\
\hline
\end{tabular}

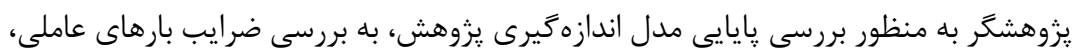

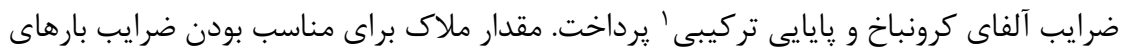

1 - Composite Reliability 

دكتر خرديار و همكاران، بر رسى اثر سلامت روانى و كمالَّايى بر تصميم تيرى اخلاقى حسابداران...

عاملى \&/• مىباشد. در جدول ץ تمامى اعداد ضرايب بارهاى عاملى سؤالات از \& • بيشتر است كه نشان از مناسب بودن اين معيار دارد.

\begin{tabular}{|c|c|c|}
\hline بار عاملى & سؤالات & عامل \\
\hline 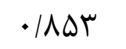 & B31 & \multirow{5}{*}{ سلامت } \\
\hline$\cdot \mid \Lambda \Lambda$. & B32 & \\
\hline - /AVV & B33 & \\
\hline$\cdot / \Lambda \wedge\rangle$ & B34 & \\
\hline . $/ \vee \wedge 9$ & B35 & \\
\hline . & C11 & \multirow{4}{*}{ فردى اهمال كارى } \\
\hline . IArG & $\mathrm{C} 12$ & \\
\hline $.19 Y \Delta$ & $\mathrm{C} 13$ & \\
\hline$\cdot \mid \mathrm{A} \Lambda$. & C14 & \\
\hline$\cdot|\Lambda| f$ & $\mathrm{C} 21$ & \multirow{4}{*}{ سازمانى كارى } \\
\hline - IATG & $\mathrm{C} 22$ & \\
\hline$\cdot|\Lambda| r$ & $\mathrm{C} 23$ & \\
\hline$\cdot 11 \cdot 9$ & $\mathrm{C} 24$ & \\
\hline$\cdot \mid \wedge \Lambda \mu$ & D1 & \multirow{5}{*}{ تصيرى } \\
\hline .1911 & D2 & \\
\hline .1190 & D3 & \\
\hline$\cdot 1110$ & D4 & \\
\hline - IVVA & D5 & \\
\hline
\end{tabular}

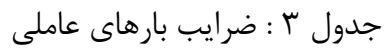

\begin{tabular}{|c|c|c|}
\hline بار عاملى & |سؤالات & عامل \\
\hline$\cdot / V V F$ & A11 & \multirow{5}{*}{ خمال گرايى } \\
\hline$\cdot / 9 Y \wedge$ & A12 & \\
\hline$\cdot 1190$ & A13 & \\
\hline$\cdot / A F V$ & A14 & \\
\hline . 1941 & A15 & \\
\hline$\cdot 19 \cdot 1$ & A21 & \multirow{5}{*}{ دمال كرايى } \\
\hline$\cdot / \Lambda \Lambda$. & A22 & \\
\hline$\cdot 11 \cdot 9$ & A23 & \\
\hline .194. & A24 & \\
\hline.$/ 9 F V$ & A 25 & \\
\hline$\cdot / \Lambda A F$ & A31 & \multirow{4}{*}{ كامعالمرايى } \\
\hline$\cdot 19 \cdot r$ & A32 & \\
\hline $.19 Y F F^{-}$ & A33 & \\
\hline . 1 १९९ & A34 & \\
\hline - IVTV & B11 & \multirow{5}{*}{ سلامت روانى } \\
\hline$\cdot 19 \cdot r$ & B12 & \\
\hline $.19 \cdot 9$ & B13 & \\
\hline - $/ A V F$ & B14 & \\
\hline - / १९V & B15 & \\
\hline - /Ars & B21 & \multirow{5}{*}{ جسمانى } \\
\hline$\cdot 19 \cdot r$ & B22 & \\
\hline$\cdot \mid A V F$ & B23 & \\
\hline$\cdot 11 \cdot 9$ & B24 & \\
\hline - IVAT & B25 & \\
\hline
\end{tabular}

با توجه به اينكه مقدار مناسب براى آلفاى كرونباخ و ويايايى تركيبى V/ • است و مطابق با

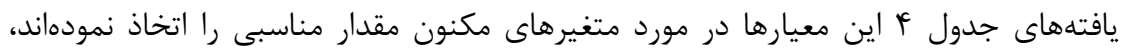

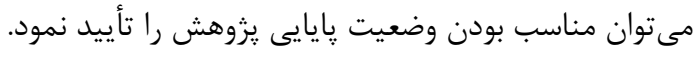


دو فصلنامه حسابدارى ارزشى و رفتارى، سال ششم، شماره يازدهم، بهار و تابستان + +ع|

\begin{tabular}{|c|c|c|}
\hline \multicolumn{3}{|c|}{ جدول fا: نتايج معيار آلفاى كرونباخ و پايايى تركيبى متغيرهاى ينهان تحقيق } \\
\hline $\begin{array}{c}\text { ضريب پايايى تركيبى } \\
(\mathrm{CR}>\cdot / \mathrm{V})\end{array}$ & $\begin{array}{c}\text { ضريب آلفاى كرونباخ } \\
\text { (Alpha>-/V) }\end{array}$ & متغيرهاى مكنون \\
\hline.$/ 9 F F$ & $.19 r \Delta$ & كمال گرايى خودمدار \\
\hline $.19 \Delta r$ & .1949 & كمال گرايى ديخرمدار \\
\hline .1949 & (19rr & كمال گرايى جامعهمدار \\
\hline . 1949 & .1914 & سلامت روانى \\
\hline $.19 T V$ & $\cdot 19 \cdot 1$ & سلامت جسمانى \\
\hline .1910 & .1914 & عملكرد اجتماعى \\
\hline $.19 T r$ & $\cdot \mid \Lambda \wedge 9$ & اهمال كارى فردى \\
\hline$\cdot 1199$ & . & اهمال كارى سازمانى \\
\hline 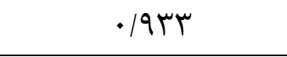 & $\cdot 19 \cdot 9$ & تصميم گيرى اخلاقى \\
\hline
\end{tabular}

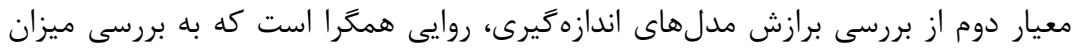

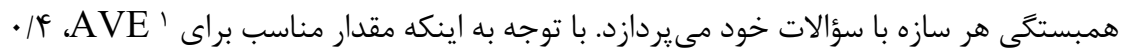

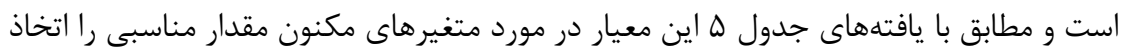

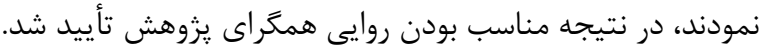
جدول ه : نتايج روايى همخرا متغيرهاى ينهان تحقيق

\begin{tabular}{|c|c|}
\hline 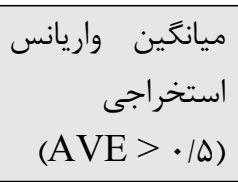 & متغيرهاى مكنون \\
\hline$\cdot|V| \mid$ & عملكرد اجتماعى \\
\hline . IVFV & اهمال كارى فردى \\
\hline .1999 & اهمال كارى سازمانى \\
\hline - $/ V T^{\prime}$ & تصميم گيرى اخلاقى \\
\hline
\end{tabular}

\begin{tabular}{|c|c|}
\hline $\begin{array}{c}\text { ميانگين واريانس } \\
\text { استخراجى } \\
(A V E>-\Delta)\end{array}$ & متغيرهاى مكنون \\
\hline$\cdot / V V I$ & كمال كرايى خودمدار \\
\hline$\cdot / \Lambda \cdot V$ & كمال گرايى ديخرمدار \\
\hline.$/ 114$ & كمال ترايى جامعلمدار \\
\hline - NVES & سلامت روانى \\
\hline$\cdot / 219$ & حسمانى \\
\hline
\end{tabular}

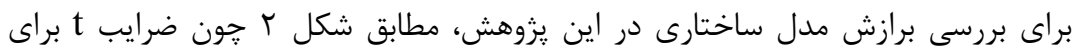

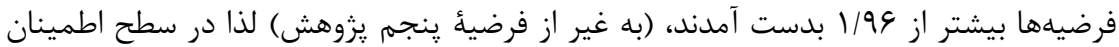

1 - Average Variance Extracted 


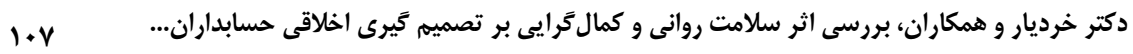

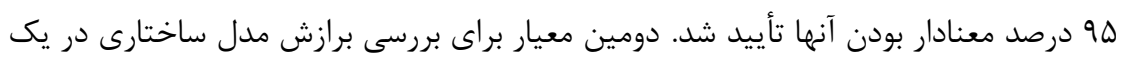

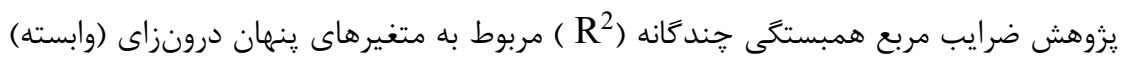

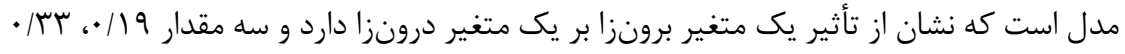

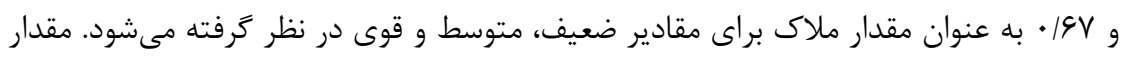

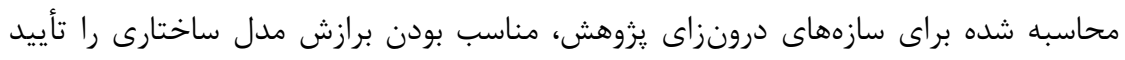
ساخت.

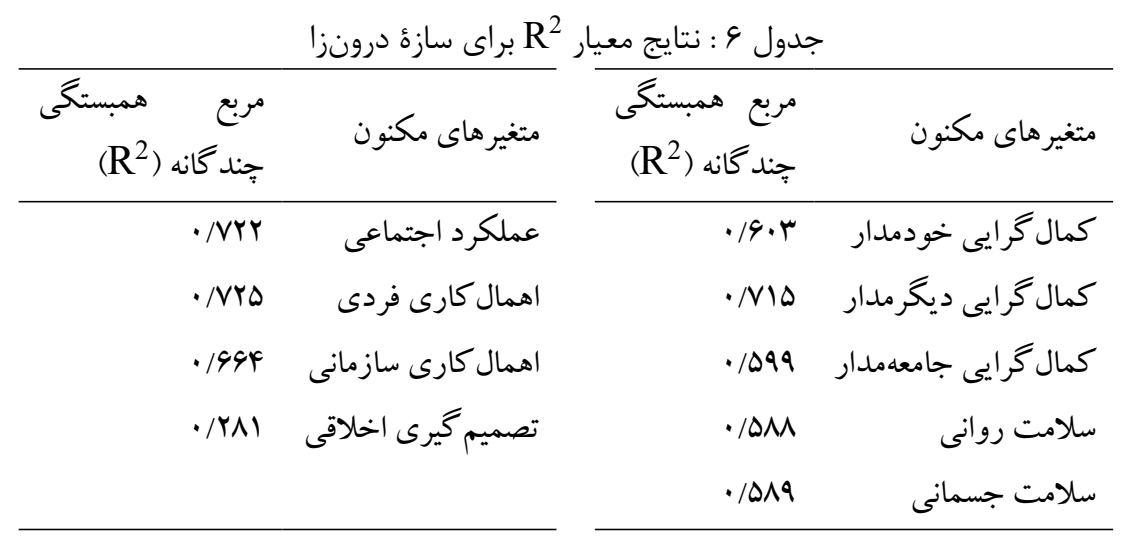

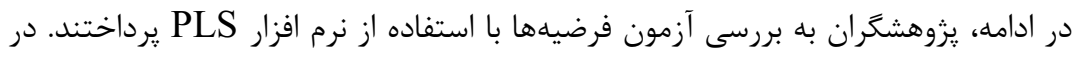

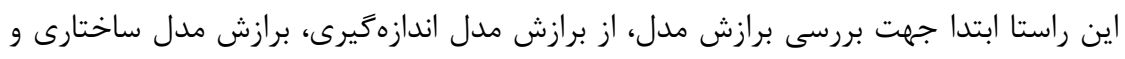
برازش كلى مدل استفاده كرديده است. 


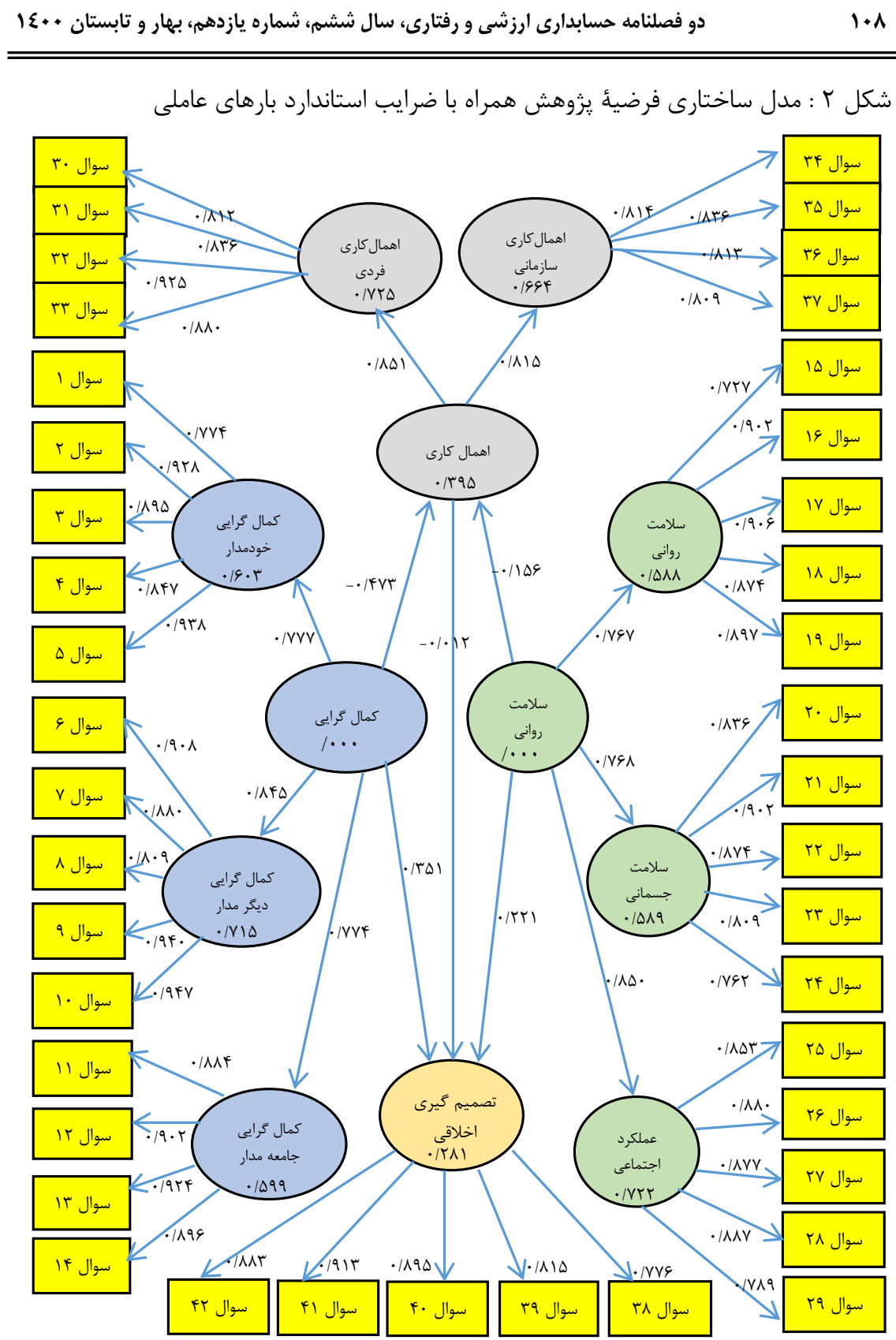


دكتر خرديار و همكاران، بررسى اثر سلامت روانى و كمالَّايى بر تصميم كيرى اخلاقى حسابداران...

شكل r : مدل ساختارى فرضيئ يزوهش همراه با ضرايب معنادارى

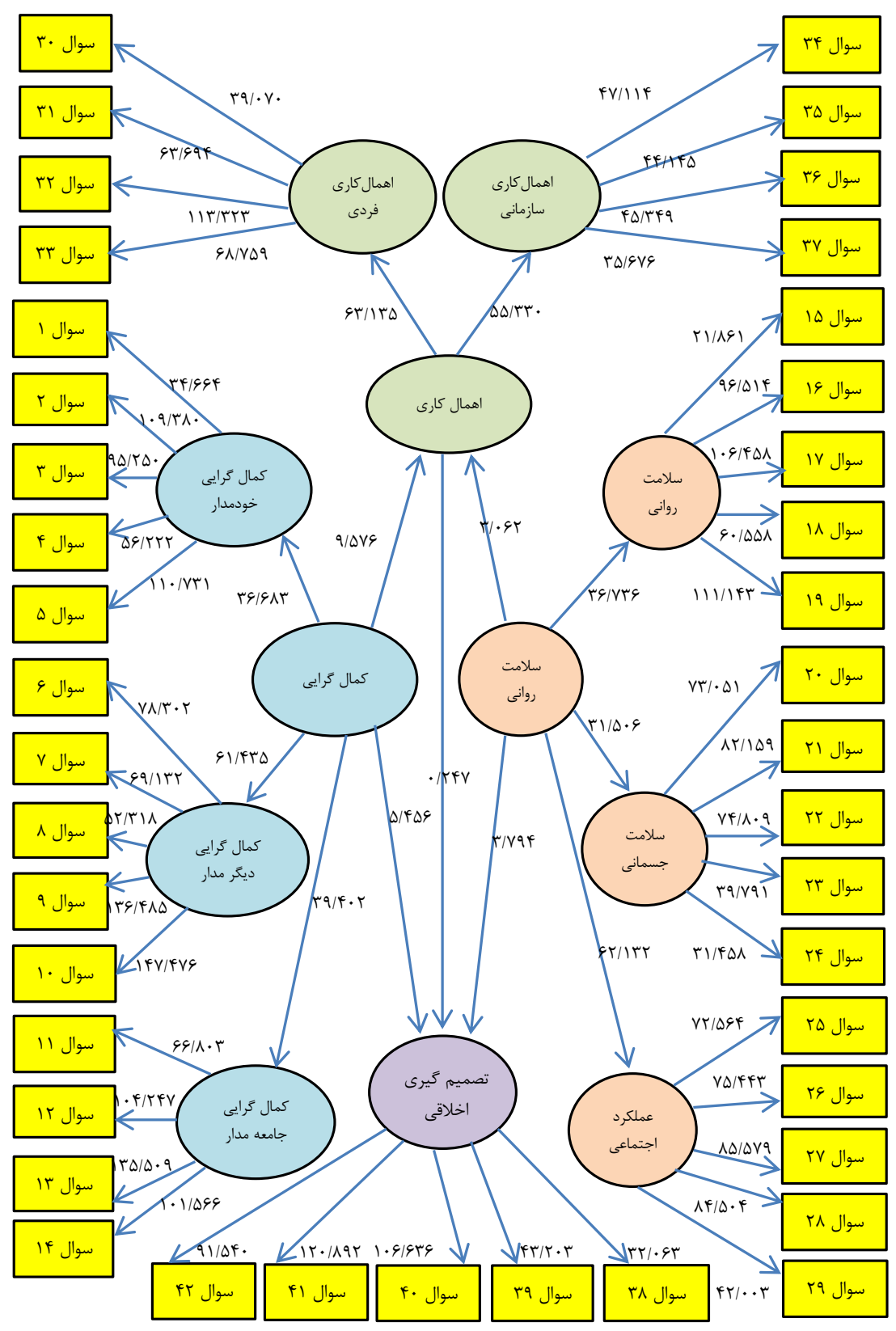




\section{برازش مدل كلى}

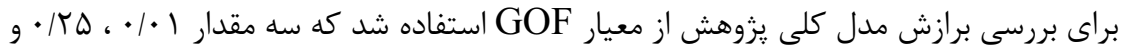

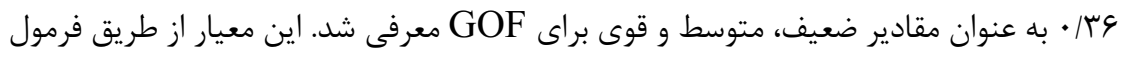

روبرو محاسبه مى گردد:

$$
\text { GOF }=\sqrt{\overline{\text { communalities }} \times \overline{R^{2}}}
$$

Communalities

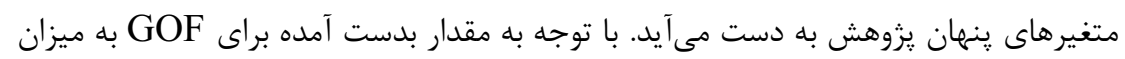

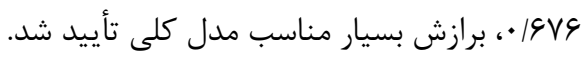

\begin{tabular}{|c|c|c|}
\hline \multicolumn{3}{|c|}{ جدول V : نتايج برازش مدل كلى } \\
\hline GOF & $\overline{R^{2}}$ & $\overline{\text { Communality }}$ \\
\hline $.19 \vee 9$ &.$|9|^{.}$ & . $/ V \Delta$. \\
\hline
\end{tabular}

\section{نتايج آزمون فرضيدهاى يزوهش}

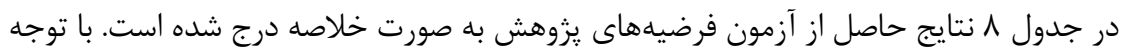

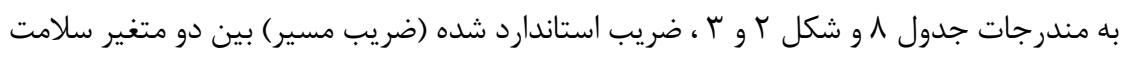

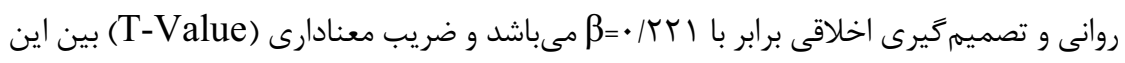

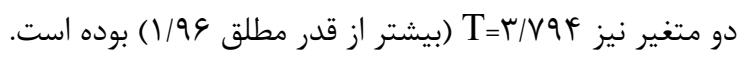

\begin{tabular}{|c|c|c|c|c|}
\hline آزتيجة & ضرنادارى & 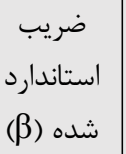 & روابط علّى بين متغيرهاى يزوهش & 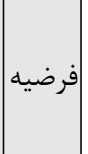 \\
\hline تأييد & $r / v q 4$ &.$|r T|$ & سلامت روانى ـ تصميمَيرى اخلاقى & اول \\
\hline تأييد & $\Delta / \uparrow \Delta \varphi$ & $\cdot / R \Delta \mid$ & كمال كرايى ـ تصميمَيرى اخلاقى & دوم \\
\hline تأييد & $r / .94$ & $-\cdot / 1 \Delta \varphi$ & سلامت روانى — اهمال كارى & 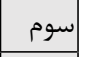 \\
\hline تأييد & $9 / \Delta \vee G$ & $-\cdot / \mu V \mu$ & كمال گرايى — اهمال كارى & |جهارم \\
\hline د) & $\cdot / T F V$ & $-\cdot \cdot \cdot 1 \mathrm{~T}$ & اهمال كارى — تصميمَيرى اخلاقى & 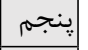 \\
\hline إ & $\cdot / T F V$ & $-\cdot / \cdot 1 T$ & 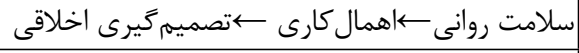 & | ششم \\
\hline د, & $\cdot \pi F V$ & $-\cdot \cdot \cdot 1 \mathrm{~T}$ & كمال كرايى ـاهمال كارى ־تصميم كيرى اخلاقى & هفتم \\
\hline
\end{tabular}

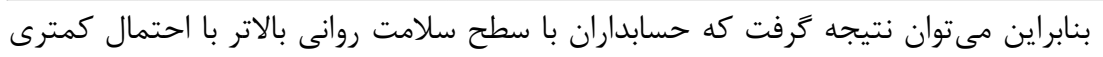

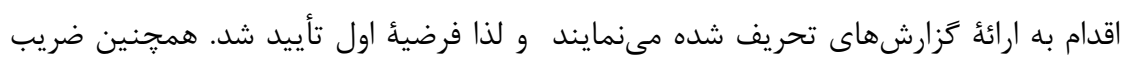




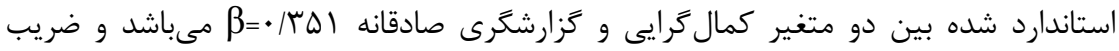

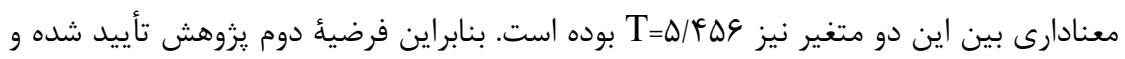

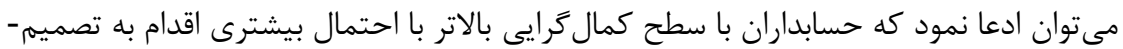

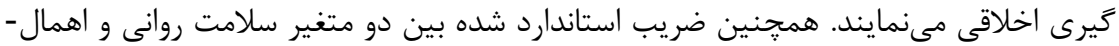

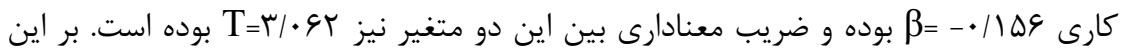

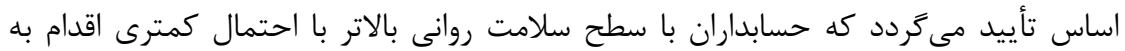

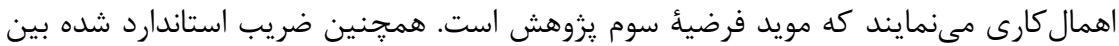

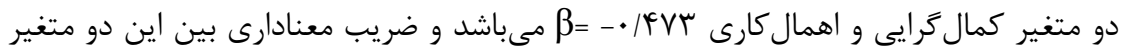

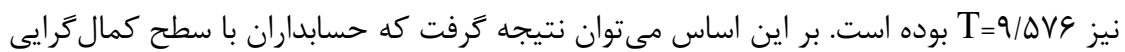

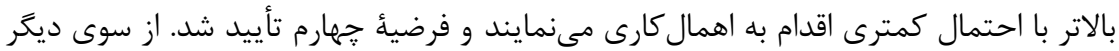

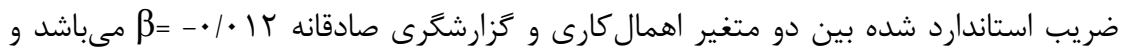

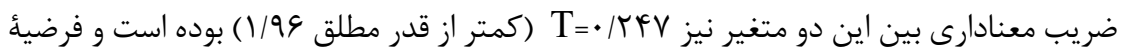

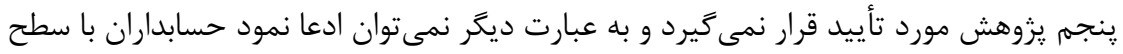

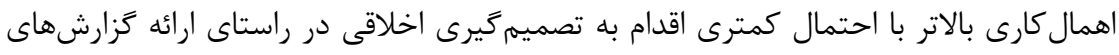

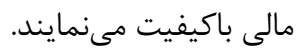

در ادامه، مدل برازش شده نشان مى دهد مقدار ضريب استاندارد شده بين دو متغير سلامت

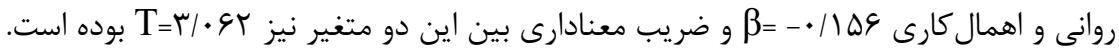

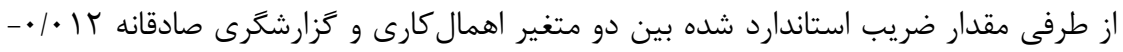

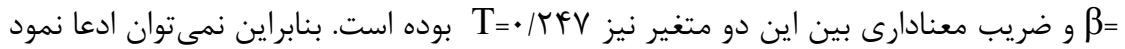

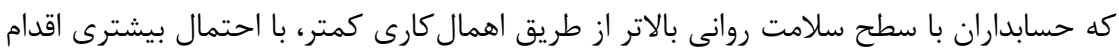

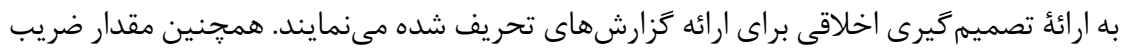

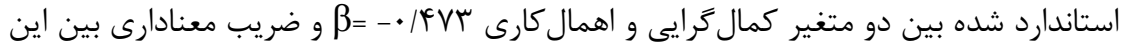

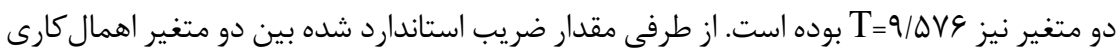

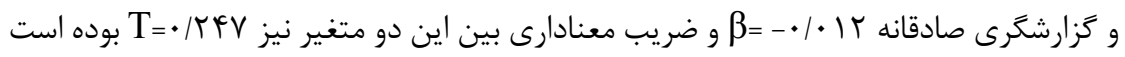
و در نتيجه فرضيأ هفتم بزوهش نيز تأييد نكرديد

9- - ونتيجه كيرى و بحث در اين يزوهش سعى شده برخى از مهمترين عوامل مؤثر در تصميمَّيرى اخلاقى حسابداران و و

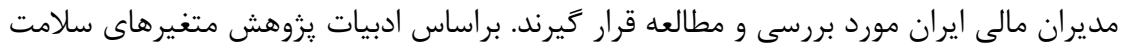
روانى، كمال 
كرفت. براساس يافتهاى يزوهش سلامت روانى و ويزگى روانى كمالَرايى منجر به افزايش

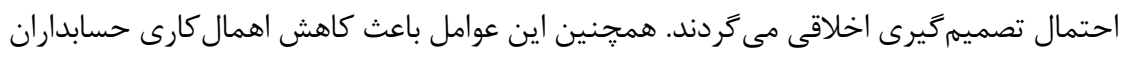

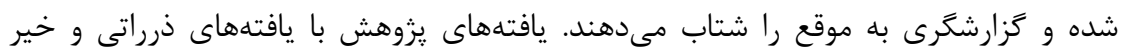

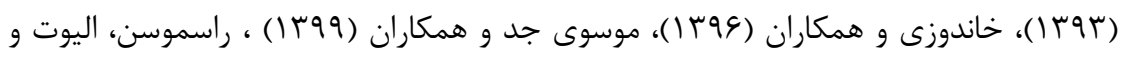

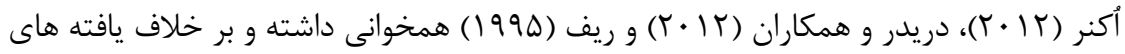

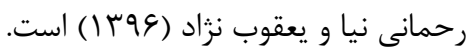
حسابدار كمال

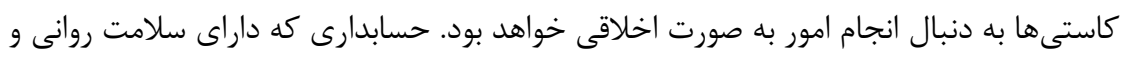

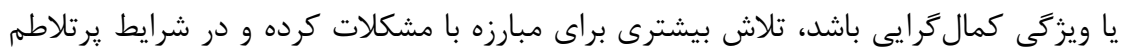

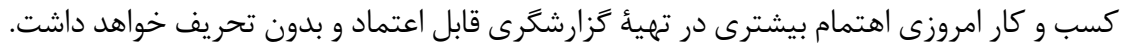

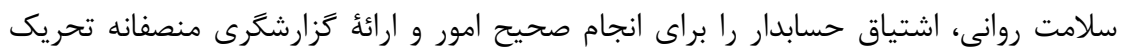

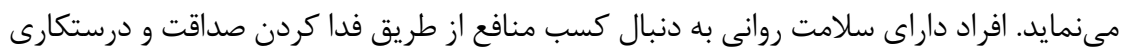

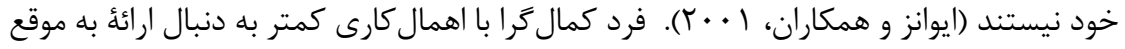

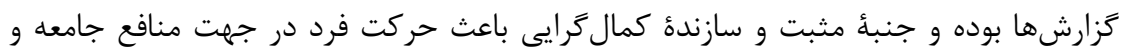

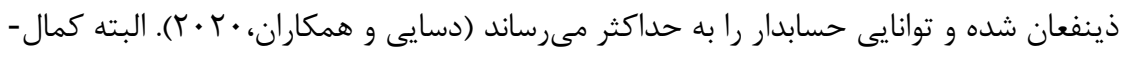

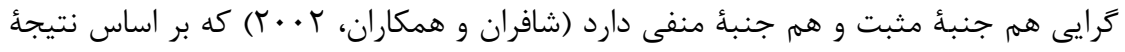

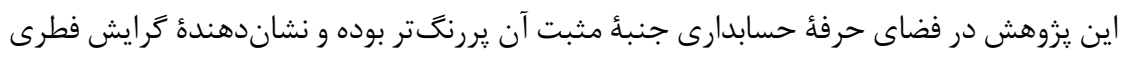

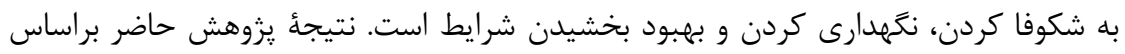

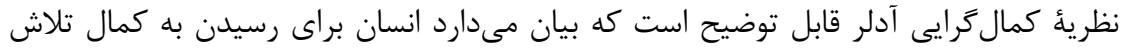

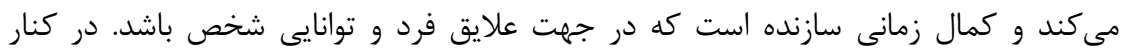

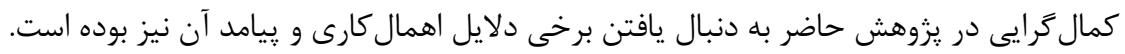

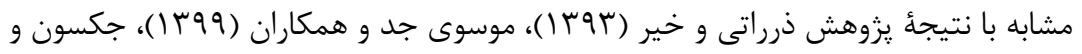

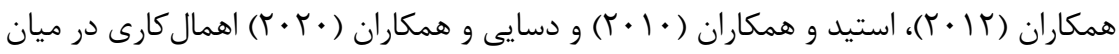

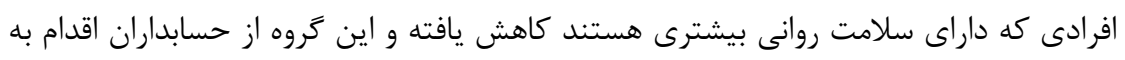

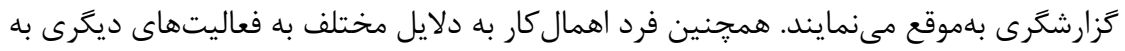

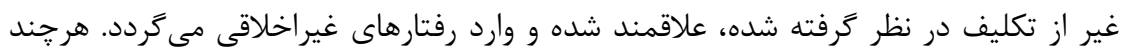

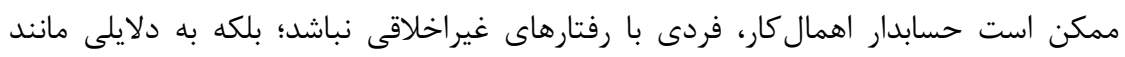

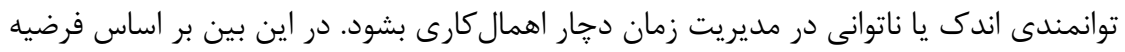
شش و هفت، نمىتوان نقش ميانجى اهمال كارى در اثر سلامت روانى و كمال گرايى مورد تائيد 

دكتر خرديار و همكاران، بررسى اثر سلامت روانى و كمالَّرايى بر تصميم كَيرى اخلاقى حسابداران... قرار داد؛ يك دليل آن عدم تاثير اهمال كارى بر تصميمَيرى اخلاقى بوده و بنابراين اين متغير نمى تواند نقش ميانجى را ايفا نمايد.

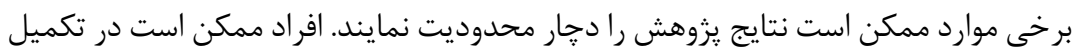

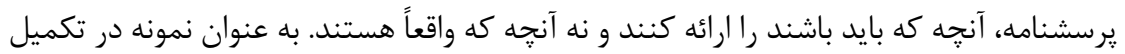

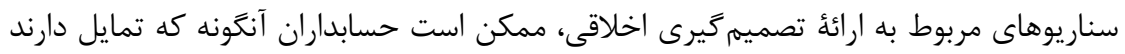

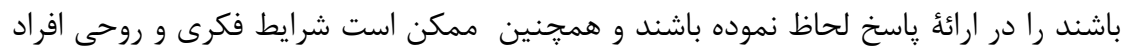
بر ي باسخها تاثير خذار بوده باشد.

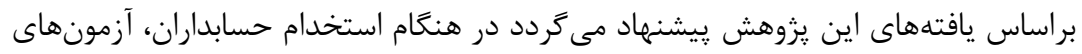

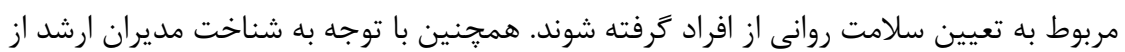

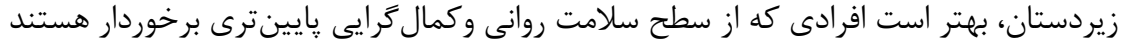

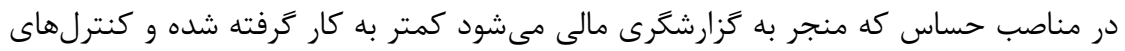

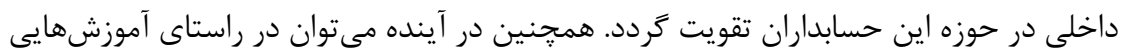
كه منجر به تقويت سلامت روانى و ساير ويزگى هاى مثبت كه منجر به اتخاذ تصميم كيرىهاى

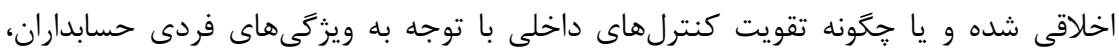
ئروهش فعلى را كسترش داد.

\section{V - تقدير و تشكر و ملاحظههاى اخلاقى}

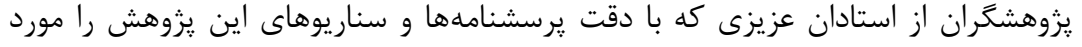

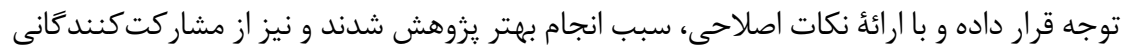

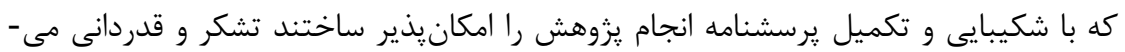
نمايند.

\section{1 - بيوست ها: برسشنامه}

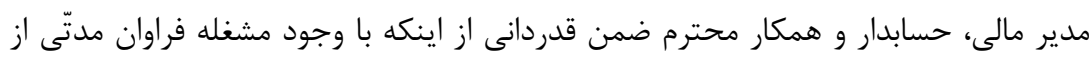

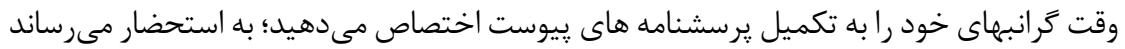

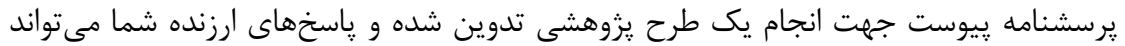

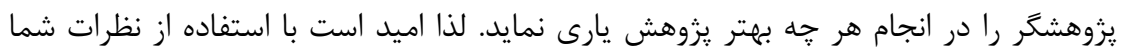

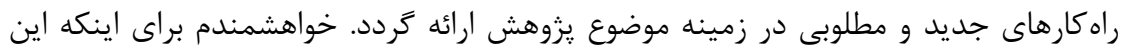
يزوهش به صورت علمى و دقيق انجام يذيرد راهنماى يرسشنامه را با دقت بخوانيد. صميمانه از از ردان

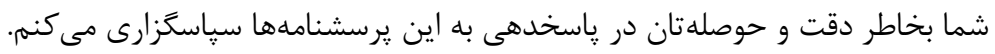




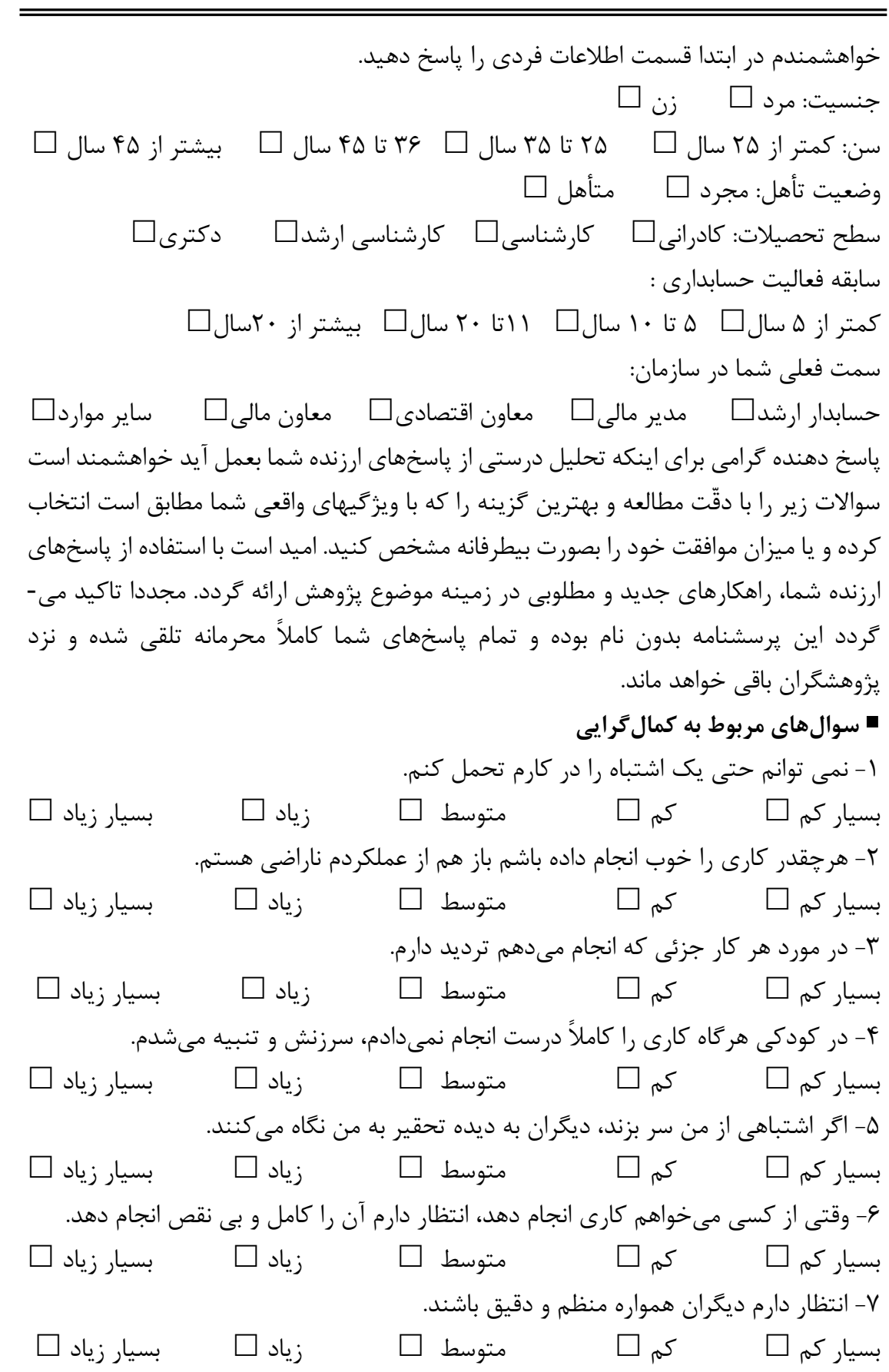




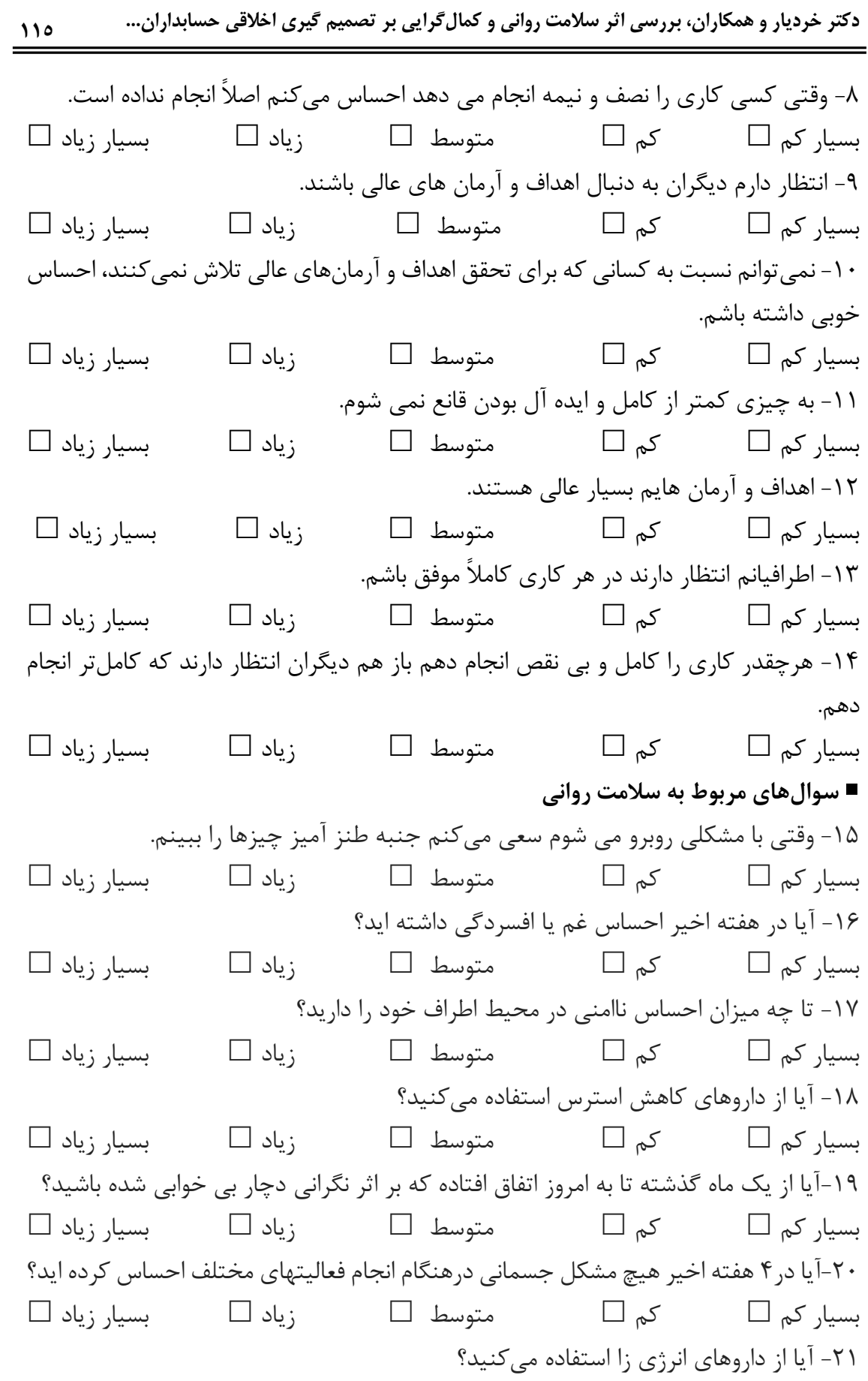




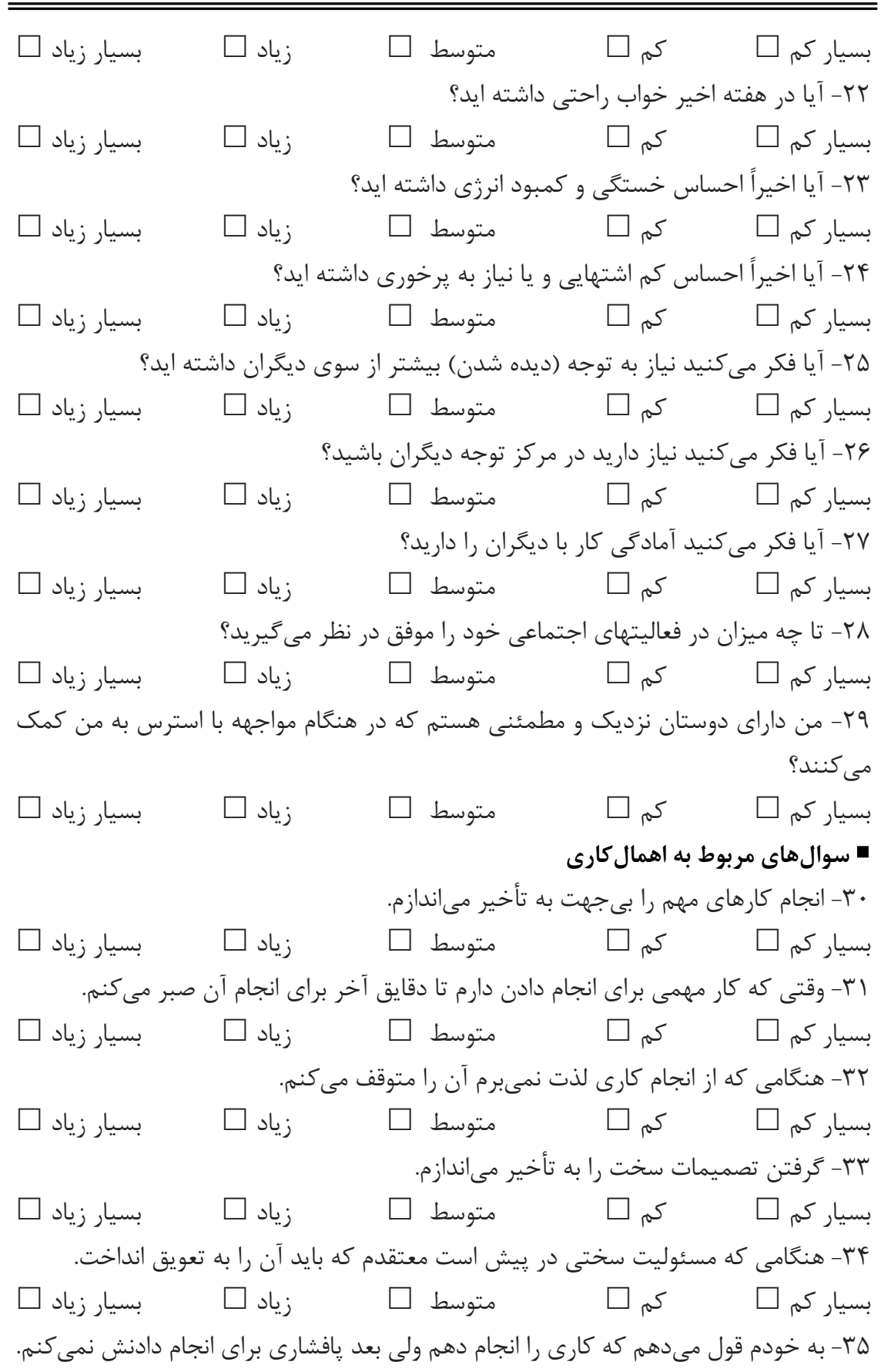



دكتر خرديار و همكاران، بررسى اثر سلامت روانى و كمالَّرايى بر تصميم تَيرى اخلاقى حسابداران...

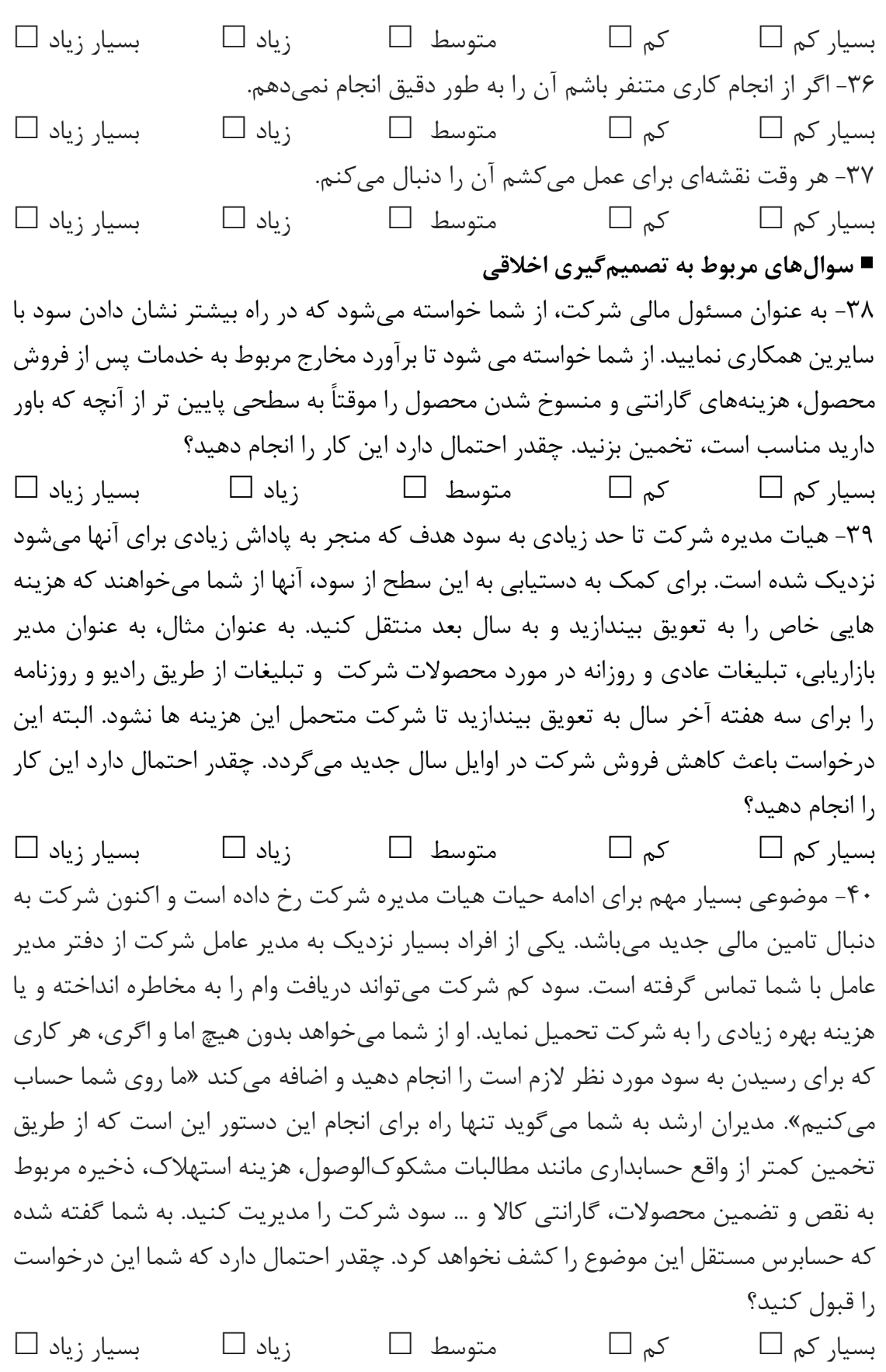


أF- مديران ارشد از شما مى خواهند از آنجا كه دستيابى به اهداف بودجه شده بسيار براى شركت

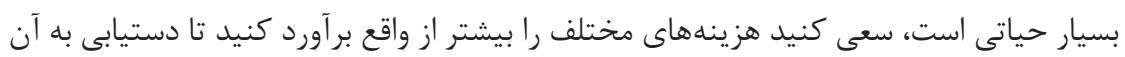

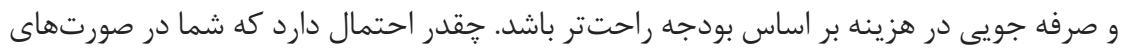

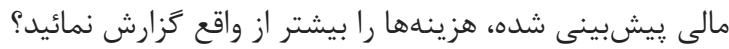

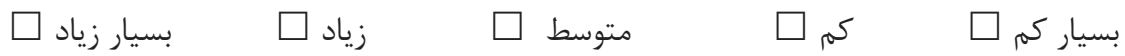

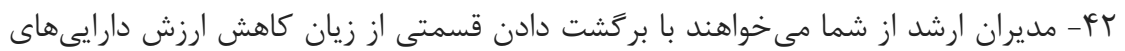

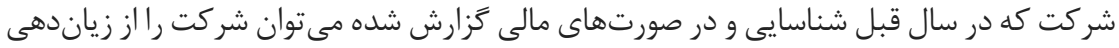

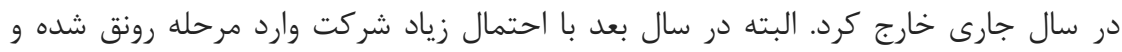

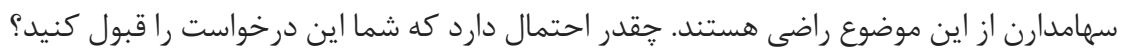

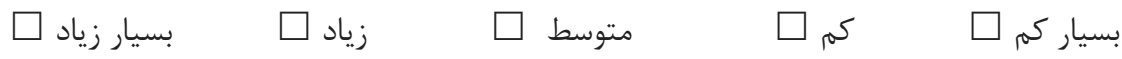

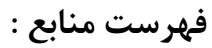

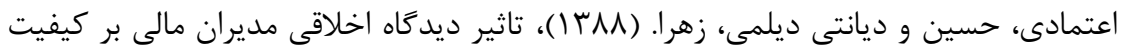

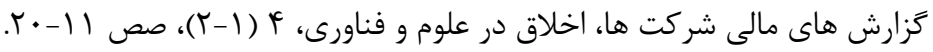

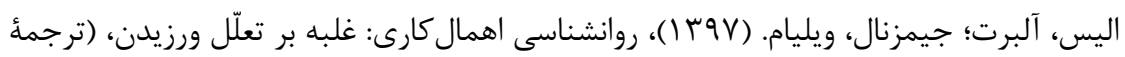
محمدعلى فرجاد)، نسخه و، تهران: نشر رشد. امينى، عليرضا و شاهين، وحيده. (99 (19)، شناسايى و سطحبندى عوامل مؤثر بر تصميمزيرى

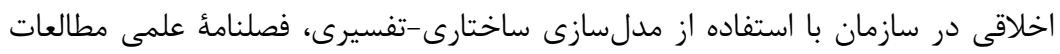

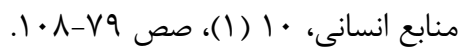

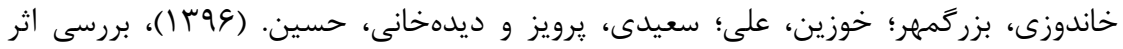

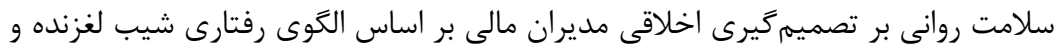

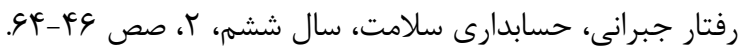

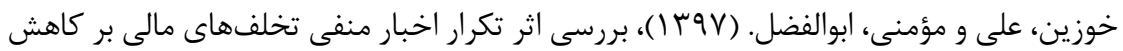

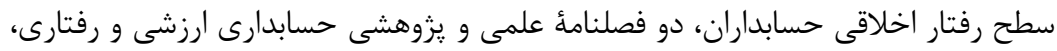

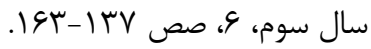
ديانتى ديلمه، زهرا؛ طيبى، وحيد. (• (1) )، تاثير ابعاد اخلاقى مديران بر كيفيت سود شركتهاى

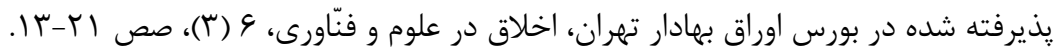

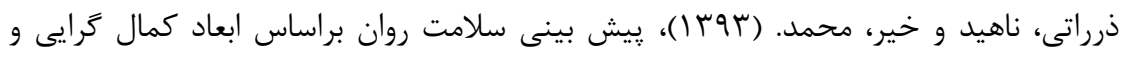

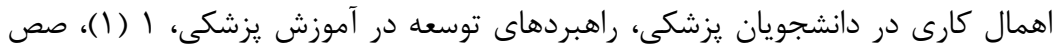




$$
\begin{aligned}
& \text { رحمانى نيا، احسان و يعقوب نزاد، احمد. (ع (9 1)، عوامل مؤثر بر تصميم گيرى اخلاقى حسابرسان }
\end{aligned}
$$

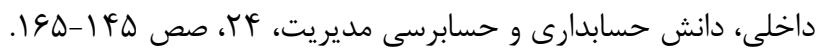

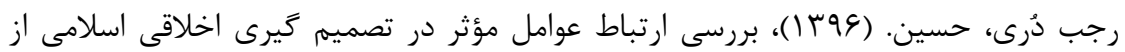

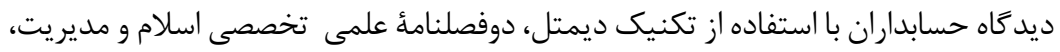

$$
\begin{aligned}
& \text {. Ir-99 }
\end{aligned}
$$

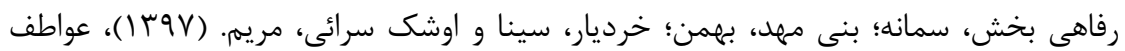

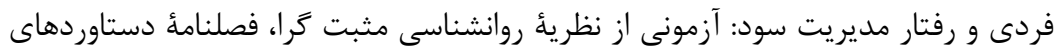

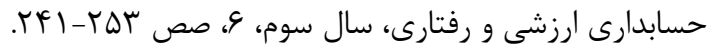

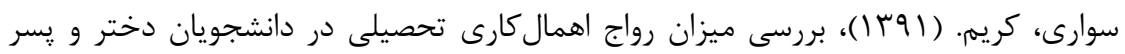

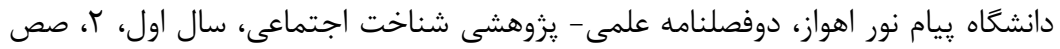

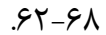

$$
\begin{aligned}
& \text { مهر كان، محمد رضا؛ درى نوكورانى، بهروز؛ جعفرى، سحر و خانى جزنى، جمال. (99 (1)، طراحى }
\end{aligned}
$$

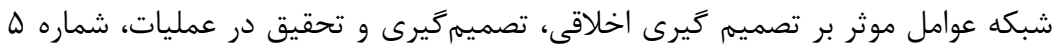

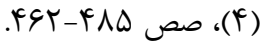

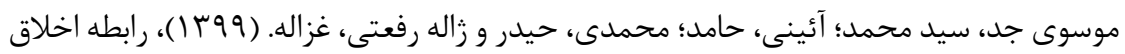

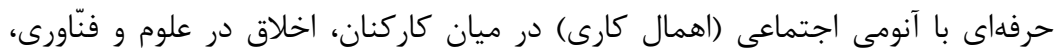

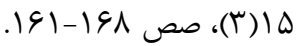

Abedi Jafari, H., A. Nave Ebrahim, A. Hassanpoor, and P. pirmaleki. 2018. Explaining the effect of intrinsic religiosity on ethical decisionmaking in business. Organizational behaviour studies quarterly. 7(2): 93-128.

Çapan, B. E. 2010. Relationship among perfectionism. academic procrastination and life satisfaction of university students. Procedia Social and Behavioral Sciences. 5: 1665-1671.

Casali, G. L., and M. Perano. 2010. Forty years of research on factors influencing ethical decision making: Establishing a future research agenda. Journal of Business Research. 132: 614-630.

Chang, C., P. L. Hewitt, G. L. Flett, and H. M. Roxborough. 2019. Multidimensional perfectionism and borderline personality organization in emerging adults: A two-wave longitudinal study. Personality and Individual Differences. 146: 143-148. 
Craft, J. L. 2013. A review of the empirical ethical decision-making literature: 2004-2011. Journal of business ethics. 117(2): 221-259.

De Ridder, D., G. Lensvelt-Mulders, C. Finkenauer, F. M. Stok, and R. F. Baumeister. 2012. A meta-analysis of how trait self-control relates to a wide range of behaviors. Personality and Social Psychology Review. 16: 76-99.

Desai N., S. P. Jain, S. Jain, and A. Tripathy. 2020. The impact of implicit theories of personality malleability on opportunistic financial reporting. Journal of Business Research. 116: 258-265.

Etzioni, A. (1988). Normative-affective factors: Toward a new decisionmaking model. Journal of economic psychology. 9(2): 125-150.

Evans, J. H., R. L. Hannan, R. Krishnan, and D. V. Moser. 2001. Honesty in Managerial Reporting. The Accounting Review. 76(4): 537-559.

Frost, R. O., and J. Henderson. 1991. Perfectionism and reactions to athletic competition. Journal of Sport and Exercise Psychology. 13: 323-335.

Jackson T., S. Weiss, and J. Lindquist. 2012. Does procrastination mediate the relationship between optimism and subsequent?. Journal of Social Behavioral Personality. 15: 203-212.

Lowe, D. J., and P. M. Reckers. 2012. An examination of the contribution of dispositional affect on ethical lapses. Journal of business ethics. 111(2): 179-193.

MacDougall, A. E., A. A. Martin, Z. Bagdasarov, \& M. D. Mumford. 2014. A review of theory progression in ethical decision making literature. Journal of organizational psychology. 14(2): 9-19.

Morgan-Lowes, K. L., P. J. F. Clarke, K. J. Hoiles, C. Y. Shu, H. J. Watson, P. D. Dunlop, and S. J. Egan. 2019. The relationships between perfectionism, anxiety and depression across time in paediatric eating disorders. Eating Behaviors. 34: 101305.

Onji, K. 2013. Estimating the effects of procrastination on performance: A small sample study. The Journal of Socio-Economics. 44: 85-90.

Rasmussen, S. A., M. A. Elliott, and R. C. O'Connor. 2012. Psychological distress and perfectionism in recent suicide attempters: The role of behavioural inhibition and activation. Personality and Individual Differences. 52(6): 680-685.

Reckers, P., and M. Samuelson. 2016. Toward resolving the debate surrounding slippery slope versus licensing behavior: The importance of individual differences in accounting ethical decision making. Advances in Accounting, incorporating Advances in International Accounting. 34: 1-16.

Ryff, C. D. 1995. Psychological well-being in adult life. Current Directions in Psychological Science. 4: 99-104. 


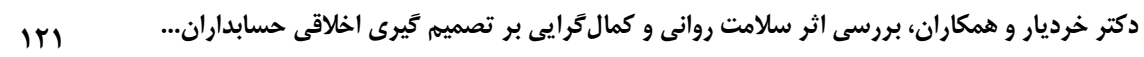

Seheni Yeylagh, M., A. Salamati, M. Mehrabizadeh Honarmand, and J. Haghighi. 2006. Prevalence of procrastination and the effects of cognitivebehavior and behavior management therapies on reduction of procrastination in male and female high school students in Ahvaz. Journal of Education and Psychology. 3(3): 1-30.

Selart, M., and S. T. Johansen. (2011). Ethical decision making in organizations: The role of leadership stress. Journal of business ethics. 99(2): 129-143.

Shafran, R., Z. Cooper, and C. G. Fairburn. 2002. Clinical perfectionism: a cognitive behavioural analysis. Behaviour Research and Therapy. 40: 773-791.

Sheehan, N. T., and J. A. Schmidt. 2015. Preparing accounting students for ethical decision making: Developing individual codes of conduct based on personal values. Journal of Accounting Education. 33 (3): 183-197.

Stead, R., M. J. Shanahan, and R. W. J. Neufeld. 2010. I'll go to Therapy, Eventually: Procrastination, Stress and Mental Health. Personality and Individual Differences. 49(3): 175-80.

Stoeber, J., A. R. Feast, \& J. A. Hayward. 2009. Self-oriented and socially prescribed perfectionism: Differential relationships with intrinsic and extrinsic motivation and test anxiety. Personality and Individual Differences. 47: 423-428.

Tuckman, B. W. 1991. The Development and Concurrent Validity of the Procrastination Scale. Educational and Psychological Measurement. 51: 473-480.

Valentine, S., \& L. Godkin. 2019. Moral intensity. ethical decision making, and whistleblowing intention. Journal of Business Research. 98: 277288.

World Health Organization. 2017. Investing in Mental Health Evidence for Action. Who Library Cataloguing-In-Publication Data. United States of America: World Health Organization. https://apps.who.int/iris/handle/10665/87232. 